\title{
Aircraft Acquisition Conceptual Framework
}

\author{
Ismail bin Yusof ${ }^{1} \&$ Abd Rahman Abdul Rahim ${ }^{1}$ \\ ${ }^{1}$ Razak School of Engineering and Advanced Technology, University Teknologi Malaysia, Kuala Lumpur, \\ Malaysia \\ Correspondence: Ismail bin Yusof, Razak School of Engineering and Advanced Technology, University \\ Teknologi Malaysia, Jalan Sultan Yahya Petra, 54100 Kuala Lumpur, Malaysia. Tel: 603-2180-5186. E-mail: \\ ismail_yusof2005@yahoo.com
}

Received: December 11, 2016

Accepted: December 23, 2016

Online Published: March 24, 2017

doi:10.5539/ass.v13n4p37

URL: http://dx.doi.org/10.5539/ass.v13n4p37

\begin{abstract}
The Royal Malaysian Air Force (RMAF) has faced difficulties in achieving and sustaining at least $70 \%$ of its aircraft availability (Av) in order to support its operational requirements. The head start for this research is to discuss with a focus group (FG) which comprise of eight officers and one moderator and supported by observation on the field. The FG highlighted that the low Av was due to the ineffectiveness and inefficiency of the through life cycle support (TLCS) as a result of weaknesses in the acquisition conceptual framework (ACF). Three research questions were put forward; Q1: Why has the RMAF not achieved its aircraft Av as its desired objectives? Q2: How do the RMAF's present acquisition practices given a significant impact to Av? And Q3: What is the recommended ACF to be used to ensure higher aircraft Av? The mix mode method (quantitative and qualitative) data collection was used. The literature review focused on critical success factors (CSFs) in terms of acquisition, terms and definition, and present practices in the Royal Malaysian Army (RMA), the Royal Malaysian Navy (RMN), the Malaysian public sector, the Department of Defence of the United States of America (DoD USA), the Ministry of Defence of United Kingdom (MoD UK) and the Australian Defence Force (ADF). Based on the CSFs from the literature review, a preliminary ACF I was developed. The RMAF case study had focused on Type A, Type B, Type C and Type D aircraft. Data on aircraft status for FY 2011 to 2015 was gathered from the Air Support Command Headquarters (ASHQ). The survey was achieved through 16 self-administered structured questionnaires which are close-ended involving 120 out of 150 respondents from the Worker Group (WG). The interviewer collected qualitative data using 21 semi-structured questionnaires with open-ended answers on 20 respondents from the Management Group (MG). The survey and interview results were presented in a matrix table and categorized in accordance with themes and their relationships. Based on the results of the case study, the preliminary ACF I was modified to ACF II. Then, ACF II was validated by four experts who comprise of two senior officers and two senior managers from the aviation industry. After validation, the ACF II was modified to ACF III (final) and was proposed for implementation. Three project objectives were put forward. Objective 1: To identify the cause of low Av. Finding 1: Av for Type A, Type B, and Type C aircraft for FY 2011 to 2015 is approximately $43 \%$ (target $\geq 70 \% \mathrm{Av}$ ). The low Av is due to aircraft downtime waiting for spare parts at the RMAF's facilities (AWP) $23.5 \%$ (target $\leq 10 \%$ ), waiting for spare parts at the second line or contractor facilities (CONT) 25\% (targeted $\leq 10 \%$ ), and under work by RMAF Technicians (IWRK) 9\% (within target $\leq 10 \%$ ). Objective 2: To identify the RMAF's present ACF and its significant impact to Av. Findings: 2: The weaknesses of CSF's integration in the present ACF which is based on an ad-hoc basis have caused ineffective and inefficient TLCS, higher AWP and CONT, and low Av as highlighted in the problem statement. Objective 3: To propose the ACF for aircraft acquisition. Finding 3: The effectiveness and efficiency of the ACF proposal requires a holistic integration of CSFs which consist of: integrated logistics support, life cycle cost calculation, ecosystem for public-private participation in defence industry, explicit acquisition management framework, regulations, policy and procedures, acquisition operational process, performance measure, competency, and good governance. This ACF ensures aircraft TLCS, low AWP, low CONT, and the achievement of Av as per the RMAF's desired objective. This study focuses on RMAF's military aircraft. Hence, application of the study results on civil aviation aircraft or other sectors might be limited and requires further research.
\end{abstract}

Keywords: Aircraft acquisition conceptual framework, critical success factors in aircraft acquisition.

\section{Introduction}

Military weapons systems have to achieve their optimum percentage of availability (Av) in order to fulfil the 
need to defend any country. The RMAF's vision is to be a dominant air power. This is in-line with its mission to defend the sovereignty and integrity of the nation and its interest through the effective use of military assets. Military operations range from war fighting, peace enforcement, evacuation programs, and peacekeeping to humanitarian tasks such as humanitarian assistance and disaster relief. Certain assets have yet to achieve the desired state of sustaining at least 70\% availability (Av) (RMAF HQ, PU 2102, 2012) which is the main issue in this research. For example, an aircraft is considered available when it is ready to support the air force's operational requirements. This research had started from a discussion with a focus group (Starr, 2014) which consists of eight senior officers led by a moderator (Salant \& Dillman, 1994) and supported by observation of actual practices in the field (Starr, 2014; Abd Rahman Abdul Rahim \& Baskh, 2003). The FG had highlighted that higher aircraft downtime and low aircraft Av were due to aircraft ineffectiveness of through life cycle support (TLCS) or life cycle management which is related to weaknesses in the acquisition process.

\subsection{Introduction to the Problem}

Aircraft availability, either in military or civil aviation should be at the optimum level in order to support an organization's operational requirements. As for many air forces, the desired state of availability is at least $70 \%$. The maximum allowable aircraft downtime due to waiting for spare parts at the first line, waiting for spare parts at the second line or contractor facilities (CONT) and in-work by the maintenance crew (IWRK) is $10 \%$ or below. As for the RMAF, it has faced difficulties in achieving and sustaining the targeted availability in order to support its operational requirements. There were three questions highlighted by this research: Why has the RMAF not achieved and sustained at least $70 \%$ of its aircraft availability? How does the RMAF's present practices given a significant impact to aircraft availability? What is the recommended acquisition conceptual framework that suits the RMAF and helps ensure high aircraft availability?

\subsection{The Importance of the Problem}

By creating an effective and efficient ACF, it is expected to be able to ensure higher aircraft Av which is in line with the RMAF's operational requirements in achieving its stipulated mission.

\subsection{Literature Review}

This section focuses on the definitions and terms used throughout this research, along with ways to conduct the focus group discussion, the acquisition practices practiced by the Malaysian Public Sector, RMA, RMN, DoD USA, MoD UK and ADF, the lessons learnt, and the research gaps in order to identify the CSFs in acquisition, lessons learnt and gaps that this research can try to fill up. This literature review also focuses on learning how to conduct a mix mode method (quantitative and qualitative) research, conduct surveys and interviews, and develop questionnaires. The literature review is started with the definition of terms used throughout this paper as shown in Table 1.

Table 1. Definition of terms

\begin{tabular}{ll}
\hline \multicolumn{1}{c}{ Term } & \multicolumn{1}{c}{ Definition } \\
\hline Availability & $\begin{array}{l}\text { Aircraft availability refers to the daily percentage or number of aircraft in serviceable condition and ready for operations } \\
\text { (RMAF HQ PU 2302, 2005; Perez et al., 2009). The ADF also used the term asset Av as one of its performance measures } \\
\text { (ADF Defence Capability, 2012). PeriyarSelvam } \text { et al. (2013) defined aircraft availability as serviceable aircraft as a result } \\
\text { of maintenance activities which consist of servicing, repair, modification, overhaul, test, check and inspection of condition. } \\
\text { Availability is one of the performance measures used to monitor system performance by the DoD USA, MoD UK, and ADF. }\end{array}$ \\
\hline Defense acquisition & $\begin{array}{l}\text { Defined as a process of defense products' life cycle management (The DoD Defense Acquisition University (DAU) Press, } \\
\text { 2016). In addition, Schwartz (2013) has generally used the terms acquisition and procurement interchangeably. }\end{array}$ \\
\hline Integrated Logistics Support & A comprehensive and structured approach to the management of total support in a system's life cycle (The USA Army \\
& Regulation 700-127, 2014; MoD UK, Joint Service Publication (JSP) 886 Volume 7 Part 1, 2012; and JSP 886, 2014) \\
\hline Total Life Cycle Support & $\begin{array}{l}\text { Refers to the supportability of aircraft during its whole life starting from the early phase of entering into service until the } \\
\text { disposal phase (DoD Federal Acquisition Regulation 2.101 (FAR 2.101), 2016; Schwartz, 2013) }\end{array}$ \\
\hline Public-Private Participation & $\begin{array}{l}\text { It is a concept of civil-military integration in the aviation defense industry that is used throughout this paper. Bellais (2014) } \\
\text { consider PPP as a means to complement public investment with private funding in defence. }\end{array}$ \\
\hline Offset & $\begin{array}{l}\text { The Department of Commerce USA (2012) - Bureau of Industry and Security defines offset in the defense trade as industrial } \\
\text { compensation arrangements requested by foreign countries as a condition of the purchase of weapon systems and services } \\
\text { from non-domestic suppliers either directly related or unrelated to the purchased weapon systems or service. }\end{array}$ \\
\hline
\end{tabular}

The literature review is conducted to identify the CSFs, gaps, and lessons learnt in acquisition. Table 2 summarizes the literature related to the critical success factors, gaps and lessons learnt in acquisition. 
Table 2. Literature review - critical success factors, gaps and lesson learned in acquisition

\begin{tabular}{|c|c|c|c|c|c|}
\hline Author, year, title & Research Problem & Data Collection & $\begin{array}{c}\text { Critical Success Factors } \\
\text { in Acquisition }\end{array}$ & Research Output & $\begin{array}{c}\text { Areas not } \\
\text { Addressed }\end{array}$ \\
\hline $\begin{array}{l}\text { Vucetic (2016). Title: Who } \\
\text { framed the F-35? } \\
\text { Government- media relations } \\
\text { in Canadian defence } \\
\text { procurement }\end{array}$ & $\begin{array}{l}\text {-national defence } \\
\text { procurement where } \\
\text { role of the news } \\
\text { media has been } \\
\text { lacking. } \\
\text { - Total cost of } \$ 9 \\
\text { billion for F35 } \\
\text { project: procedural } \\
\text { wrong-doing, scandal } \\
\text { and ministerial } \\
\text { irresponsibility \& } \\
\text { misleading cost. }\end{array}$ & $\begin{array}{l}\text {-Analysis of F-35 } \\
\text { fighter jet } \\
\text { procurement } \\
\text { controversy. } \\
\text { - Analysis of } \\
\text { articles from five } \\
\text { newspapers e.g. the } \\
\text { Globe, and the } \\
\text { Toronto Star. }\end{array}$ & $\begin{array}{l}\text { PPP e.g. Department of } \\
\text { Public Works and } \\
\text { Government Services } \\
\text { Canada (PWGSC) } \\
\text { works with Lockheed } \\
\text { Martin company (OEM } \\
\text { for F-35), Policy e.g. } \\
\text { Defence Acquisition } \\
\text { Guide (DAG), contract, } \\
\text { good governance, cost, } \\
\text { PM (cost) }\end{array}$ & $\begin{array}{l}\text { - F35 case, media } \\
\text { challenged the } \\
\text { government decision e.g. } \\
\text { for cost misleading etc. } \\
\text {-ageing CF-18 fighter } \\
\text { replaced by } 65 \text { F-35s. } \\
\text {-a policy "reset,"' and } \\
\text { start all over again with } \\
\text { new monitoring body } \\
\text { namely the National } \\
\text { Fighter Procurement } \\
\text { Secretariat (NFPS) to } \\
\text { ensure good governance. }\end{array}$ & $\begin{array}{l}\text { ILS, AOP, } \\
\text { AMF, } \\
\text { competency }\end{array}$ \\
\hline $\begin{array}{l}\text { Juanita et al. (2016). } \\
\text { Title: Procurement fraud in } \\
\text { the US Department of } \\
\text { Defence -Implications for } \\
\text { contracting processes and } \\
\text { internal controls }\end{array}$ & $\begin{array}{l}\text { Procurement fraud } \\
\text { incidents in the DoD } \\
\text { USA }\end{array}$ & $\begin{array}{l}\text { Qualitative case } \\
\text { study in DoD office } \\
\text { e.g. analysis of } \\
\text { contract } \\
\text { management } \\
\text { processes }\end{array}$ & $\begin{array}{l}\text { Ethical (good } \\
\text { governance), PM } \\
\text { (performance reviews), } \\
\text { contract management } \\
\text { processes (AMF), } \\
\text { suppliers (logistic } \\
\text { support), policies, } \\
\text { procedures, specific } \\
\text { education, training and } \\
\text { experience requirements } \\
\text { (competency) }\end{array}$ & $\begin{array}{l}\text { the source selection phase } \\
\text { and contract management } \\
\text { had the majority fraud } \\
\text { incidents in DoD and } \\
\text { require support by } \\
\text { effective policies and } \\
\text { procedures. }\end{array}$ & $\begin{array}{l}\text { PPP, cost } \\
\text { (limited } \\
\text { discussion) }\end{array}$ \\
\hline $\begin{array}{l}\text { Miller and Ray (2015). Title: } \\
\text { Moving from Best Practices } \\
\text { to Standard Practices in } \\
\text { Defence Acquisition }\end{array}$ & $\begin{array}{l}\text { Isolated best } \\
\text { practices that failed } \\
\text { to become } \\
\text { widespread standard } \\
\text { practices. }\end{array}$ & $\begin{array}{l}\text { Case Study } \\
\text { (interview } \\
\text { \& observation) on } \\
\text { Defence } \\
\text { Contractor, } \\
\text { Manufacturer, } \\
\text { Mutual } \\
\text { Insurance, and } \\
\text { Structural } \\
\text { Fabrications. }\end{array}$ & $\begin{array}{l}\mathrm{PPP}, \mathrm{AOP}, \text { cost, } \mathrm{PM}, \\
\text { and } \mathrm{AMF}\end{array}$ & $\begin{array}{l}\text { Process standard: } \\
\text { inherent stakes, work } \\
\text { replicability, organization } \\
\text { alignment, making } \\
\text { advantages visible, } \\
\text { standard work } \\
\text { and compliance. }\end{array}$ & $\begin{array}{l}\text { ILS, reg., } \\
\text { competency, } \\
\text { governance }\end{array}$ \\
\hline $\begin{array}{l}\text { Chad and Stephen (2015). } \\
\text { Title: Conceptual Framework } \\
\text { for Defence Acquisition } \\
\text { Decision Makers: } \\
\text { Giving the schedule Its Due. }\end{array}$ & $\begin{array}{l}\text { Failure to develop a } \\
\text { theoretical } \\
\text { framework } \\
\text { within the acquisition } \\
\text { system. }\end{array}$ & $\begin{array}{l}\text {-Literature review } \\
\text {-Archival }\end{array}$ & $\begin{array}{l}\text { PPP, regulation, cost, } \\
\text { PM, acquisition } \\
\text { management }\end{array}$ & $\begin{array}{l}\text { Conceptual models based } \\
\text { on economic and } \\
\text { operations research } \\
\text { principles. }\end{array}$ & $\begin{array}{l}\text { ILS, AOP, } \\
\text { competency, } \\
\text { governance }\end{array}$ \\
\hline $\begin{array}{l}\text { Gaither (2014). } \\
\text { Title: Incorporating } \\
\text { Market-Based } \\
\text { Decision-Making Processes } \\
\text { in Defence Acquisitions }\end{array}$ & $\begin{array}{l}\text { Developing major } \\
\text { weapon systems too } \\
\text { often incurs } \\
\text { significant } \\
\text { cost overruns }\end{array}$ & $\begin{array}{l}\text {-Literature review } \\
\text {-Archival }\end{array}$ & $\begin{array}{l}\text { PPP, limited discussion } \\
\text { on AOP, cost, PM, and } \\
\text { limited discussion on } \\
\text { AMF }\end{array}$ & $\begin{array}{l}\text { Defence Acquisition } \\
\text { Bonds introduces a } \\
\text { financial intermediary and } \\
\text { investors into acquisition } \\
\text { process. }\end{array}$ & $\begin{array}{l}\text { ILS, reg, } \\
\text { competency, and } \\
\text { good } \\
\text { governance }\end{array}$ \\
\hline $\begin{array}{l}\text { Burgess and Balakrishnan } \\
\text { (2014) } \\
\text { Title: Challenges in Matching } \\
\text { Performance Metrics } \\
\text { to Defence Acquisition }\end{array}$ & $\begin{array}{l}\text { identify the } \\
\text { performance } \\
\text { measures best } \\
\text { suited to support } \\
\text { military acquisition } \\
\text { activities }\end{array}$ & $\begin{array}{l}\text { Case study - } \\
\text { interview on: } \\
\text {-MoD (UK) } \\
\text {-National Audit } \\
\text { Office (NAO). } \\
\text {-Five } \\
\text { major UK based } \\
\text { defence suppliers. } \\
\text { A review of the } \\
\text { measurement } \\
\text { methodologies used } \\
\text { by all of these } \\
\text { parties in military } \\
\text { acquisition } \\
\text { activities }\end{array}$ & $\begin{array}{l}\text { Focused on PM, cost, } \\
\text { limited discussion on } \\
\text { PPP }\end{array}$ & $\begin{array}{l}\text { No clear set of measures } \\
\text { is yet available. } \\
\text { An extended research } \\
\text { program will be required }\end{array}$ & $\begin{array}{l}\text { ILS, reg, AOP, } \\
\text { AMF, } \\
\text { competency and } \\
\text { governance. }\end{array}$ \\
\hline $\begin{array}{l}\text { Eßig et al. (2014) } \\
\text { Title: } \\
\text { Exposure-Capacity-Portfolio } \\
\text { for Defense } \\
\text { Supply Chains - The Case of } \\
\text { the Military Airlifter A400M. }\end{array}$ & $\begin{array}{l}\text { Lacks of } \\
\text { management tools to } \\
\text { better steer the } \\
\text { Defence industry }\end{array}$ & $\begin{array}{l}\text { Case Study - } \\
\text { Military } \\
\text { Airlifter A400M }\end{array}$ & $\begin{array}{l}\text { Supply change } \\
\text { management (Logistic } \\
\text { support), PPP, cost, } \\
\text { PM - expenditure cost, } \\
\text { AMF }\end{array}$ & $\begin{array}{l}\text { Develop the management } \\
\text { tool enabling armed } \\
\text { forces to better steer the } \\
\text { defence industry, reducing } \\
\text { the procurement } \\
\text { expenditures. }\end{array}$ & $\begin{array}{l}\text { Reg, AOP, } \\
\text { competency and } \\
\text { governance }\end{array}$ \\
\hline $\begin{array}{l}\text { Caldwell and Howard (2014). } \\
\text { Title: Contracting for } \\
\text { complex performance in }\end{array}$ & $\begin{array}{l}\text { The impact \& } \\
\text { challenges of } \\
\text { contractual }\end{array}$ & $\begin{array}{l}\text { Case study: Major } \\
\text { military platforms } \\
\text { (naval and air }\end{array}$ & $\begin{array}{l}\text { Supply chain, PPP, PM } \\
\text { (outcome-based } \\
\text { contracting) }\end{array}$ & $\begin{array}{l}\text { The new contractual } \\
\text { arrangements show an } \\
\text { increasing shift in }\end{array}$ & $\begin{array}{l}\text { Reg, AOP, cost, } \\
\text { AMF, } \\
\text { competency and }\end{array}$ \\
\hline
\end{tabular}




\begin{tabular}{|c|c|c|c|c|c|}
\hline Author, year, title & Research Problem & Data Collection & $\begin{array}{l}\text { Critical Success Factors } \\
\text { in Acquisition }\end{array}$ & Research Output & $\begin{array}{c}\text { Areas not } \\
\text { Addressed }\end{array}$ \\
\hline $\begin{array}{l}\text { markets of few buyers and } \\
\text { sellers }\end{array}$ & $\begin{array}{l}\text { arrangement on UK } \\
\text { military procurement } \\
\text { and other limited. }\end{array}$ & $\begin{array}{l}\text { defence). } \\
\text {-Interview } \\
\text {-Archives }\end{array}$ & & $\begin{array}{l}\text { responsibility to the prime } \\
\text { contractor }\end{array}$ & governance. \\
\hline $\begin{array}{l}\text { Aguado-Romero } \text { et al. (2013) } \\
\text { Title: } \\
\text { Auditing defence } \\
\text { procurement } \\
\text { contracts in the European } \\
\text { context: an inter-country } \\
\text { analysis. }\end{array}$ & $\begin{array}{l}\text { A problem arises in } \\
\text { most developed } \\
\text { countries concerning } \\
\text { the existence of a } \\
\text { non-competitive } \\
\text { market. } \\
\end{array}$ & $\begin{array}{l}\text { Comparative } \\
\text { analysis: Case } \\
\text { Study in Four } \\
\text { European countries } \\
\text { (UK, France, Spain } \\
\text { and Norway) } \\
\text {-Literature } \\
\text {-Archival } \\
\end{array}$ & $\begin{array}{l}\text { PPP, regulation, cost, } \\
\mathrm{PM}-\text { cost }\end{array}$ & $\begin{array}{l}\text { The contract auditing } \\
\text { models } \\
\text { do not present a high } \\
\text { degree of harmonization } \\
\text { of defence contract cost } \\
\text { evaluation. }\end{array}$ & $\begin{array}{l}\text { ILS, AOP, } \\
\text { AMF, } \\
\text { competency and } \\
\text { governance. }\end{array}$ \\
\hline $\begin{array}{l}\text { Stewart and Ablong (2013). } \\
\text { Title: } \\
\text { Australian defence } \\
\text { procurement goes wrong: } \\
\text { Improving outcomes in a } \\
\text { troubled contractual }\end{array}$ & $\begin{array}{l}\text { Problems with } \\
\text { schedule and budget } \\
\text { overruns in } \\
\text { Australian defence } \\
\text { procurement }\end{array}$ & Three Case studies & $\begin{array}{l}\text { PPP, regulation, AOP, } \\
\text { cost, } \mathrm{PM} \text { (value for } \\
\text { money), competency, } \\
\text { good governance }\end{array}$ & $\begin{array}{l}\text { Business process reforms, } \\
\text { tightening control and } \\
\text { improving } \\
\text { professionalism. } \\
\text { the importance of } \\
\text { relational factors of trust, } \\
\text { collaboration and } \\
\text { risk-sharing }\end{array}$ & ILS and AMF \\
\hline $\begin{array}{l}\text { Schwartz (2013) } \\
\text { Title: } \\
\text { Defence Acquisitions: How } \\
\text { DOD Acquires Weapon } \\
\text { Systems and Recent Efforts } \\
\text { to Reform the Process. }\end{array}$ & $\begin{array}{l}\text { Both Congress and } \\
\text { DoD USA focused to } \\
\text { improve defence } \\
\text { acquisitions through } \\
\text { better buying power } \\
\text { initiative }\end{array}$ & $\begin{array}{l}\text { Case study: DoD } \\
\text { USA }\end{array}$ & $\begin{array}{l}\text { ILS, PPP, statutory and } \\
\text { regulatory, AOP, LCC } \\
\text { (budget), PM (Av \& } \\
\text { PBL), AMF, and } \\
\text { competency }\end{array}$ & $\begin{array}{l}\text { Reformed: DoD launched } \\
\text { the "Better Buying Power } \\
2.0 \text { " initiative e.g. Using } \\
\text { appropriate contract type, } \\
\text { depending on the situation } \\
\text { (not limiting to } \\
\text { firm-fix-price contract). }\end{array}$ & $\begin{array}{l}\text { Limited } \\
\text { discussion on } \\
\text { good } \\
\text { governance }\end{array}$ \\
\hline $\begin{array}{l}\text { Rosen (2013) } \\
\text { Title: } \\
\text { Strategic Planning and } \\
\text { Management in Defence } \\
\text { Systems Acquisition }\end{array}$ & $\begin{array}{l}\text { Strengthen the } \\
\text { management of } \\
\text { defence } \\
\text { acquisition } \\
\text { organizations or } \\
\text { programs }\end{array}$ & $\begin{array}{l}\text { Survey of the } \\
\text { defence acquisition } \\
\text { community }\end{array}$ & $\begin{array}{l}\text { PM (Direct measurable), } \\
\text { attitude towards good } \\
\text { governance }\end{array}$ & $\begin{array}{l}\text { Use SP\&M } \\
\text { methods to strengthen the } \\
\text { management of defence } \\
\text { acquisition organizations }\end{array}$ & $\begin{array}{l}\text { ILS, PPP, } \\
\text { regulation, AOP, } \\
\text { cost, AMF and } \\
\text { competency }\end{array}$ \\
\hline $\begin{array}{l}\text { Bowyer et al. (2012) } \\
\text { Title: } \\
\text { How to acquire aircraft? } \\
\text { A grounded theory approach } \\
\text { to case study research }\end{array}$ & $\begin{array}{l}\text { The investment } \\
\text { decision to acquire } \\
\text { aircraft within an } \\
\text { industry that is small } \\
\text { by world standards. }\end{array}$ & $\begin{array}{l}\text { Case study. Primary } \\
\text { data from } \\
\text { semi-structured and } \\
\text { open-ended } \\
\text { interviews. } \\
\text { Secondary data: } \\
\text { pro-forma aircraft } \\
\text { lease }\end{array}$ & $\begin{array}{l}\text { ILS - Engineering } \\
\text { requirement, cost, PM } \\
\text { (Cost and profit), AMF } \\
\text { (limited to Model for } \\
\text { Aircraft acquisition) }\end{array}$ & $\begin{array}{l}\text { Model aircraft } \\
\text { acquisition } \\
\text { decision-making focus on: } \\
\text { financing: buy, lease or } \\
\text { contract. economic, } \\
\text { political, environmental } \\
\text { competitive\& engineering } \\
\text { requirement. }\end{array}$ & $\begin{array}{l}\text { PPP, regulation, } \\
\text { AOP, } \\
\text { competency and } \\
\text { governance }\end{array}$ \\
\hline $\begin{array}{l}\text { Euske } \text { et al. (2012) } \\
\text { Title: How does the Cost } \\
\text { Performance of Defense } \\
\text { Contracts Vary Among } \\
\text { Services and Contractors? }\end{array}$ & $\begin{array}{l}\text { The cost performance } \\
\text { of defence contracts } \\
\text { varies among the Air } \\
\text { Force, Army, Navy, } \\
\text { and the DoD and } \\
\text { among industries. } \\
\text { Evidence from Major } \\
\text { Defense Acquisition } \\
\text { Programs (MDAP) }\end{array}$ & $\begin{array}{l}\text { Collect data from } \\
\text { defence acquisition } \\
\text { management } \\
\text { information } \\
\text { retrieval (DAMIR) }\end{array}$ & $\begin{array}{l}\text { PPP, regulation, cost, } \\
\text { PM }\end{array}$ & $\begin{array}{l}\text { Data analysis indicates } \\
\text { that the Navy ranks last } \\
\text { among the military } \\
\text { services and DoD in cost } \\
\text { performance for MDAP } \\
\text { contracts, while the Air } \\
\text { Force ranks best. Of the } \\
\text { defense contractors, } \\
\text { Raytheon ranks last in } \\
\text { cost performance }\end{array}$ & $\begin{array}{l}\text { ILS, AOP, } \\
\text { AMF, } \\
\text { competency and } \\
\text { governance }\end{array}$ \\
\hline $\begin{array}{l}\text { Venelin (2010) } \\
\text { Title: Modelling Defence } \\
\text { Acquisition Strategy }\end{array}$ & $\begin{array}{l}\text { Model the process of } \\
\text { defence acquisition } \\
\text { strategy development }\end{array}$ & $\begin{array}{l}\text { Modelling the } \\
\text { defence acquisition } \\
\text { Process }\end{array}$ & $\begin{array}{l}\text { PPP, regulation, PM } \\
\text { ( Balanced scorecard } \\
(\mathrm{BSC}) \text { ) }\end{array}$ & $\begin{array}{l}\text { Modelling: } \\
\text {-Desired military } \\
\text { capabilities, the defence } \\
\text { missions and tasks, the } \\
\text { nation's defence policy, in } \\
\text { line with the level of } \\
\text { ambition, budget resource } \\
\text { restrictions, and level of } \\
\text { associated risk }\end{array}$ & $\begin{array}{l}\text { ILS, AOP, cost, } \\
\text { AMF, } \\
\text { competency and } \\
\text { governance. }\end{array}$ \\
\hline $\begin{array}{l}\text { Lavallee (2010) } \\
\text { Title: } \\
\text { Civil-Military Integration: } \\
\text { The Politics of Outsourcing }\end{array}$ & $\begin{array}{l}\text { Globalizing defence } \\
\text { industrial sector } \\
\text { through the concept } \\
\text { of civil-military } \\
\text { integration poses } \\
\text { unique challenges for } \\
\text { U.S. strategic policy. }\end{array}$ & $\begin{array}{l}\text {-Literature review. } \\
\text {-Archival }\end{array}$ & $\begin{array}{l}\text { PPP, cost, PM (Cost, } \\
\text {-Schedules, and } \\
\text {-Performance. } \\
\text { (Cheaper, Faster, Better) }\end{array}$ & $\begin{array}{l}\text { US Defence Reform } \\
\text { Initiative (DRI) (1997): } \\
\text { The Push to go } \\
\text { commercial }\end{array}$ & $\begin{array}{l}\text { ILS, regulation, } \\
\text { AOP, AMF, } \\
\text { competency and } \\
\text { governance }\end{array}$ \\
\hline $\begin{array}{l}\text { Perez et al. (2009) } \\
\text { Title: Acquisition and } \\
\text { Development Methodology } \\
\text { of Aircraft, Systems and }\end{array}$ & $\begin{array}{l}\text { Organizing the } \\
\text { planning and } \\
\text { execution of phases } \\
\text { and main events of }\end{array}$ & $\begin{array}{l}\text {-Literature review. } \\
\text {-A processes } \\
\text { modelling } \\
\text { methodology }\end{array}$ & $\begin{array}{l}\text { limited discussion on } \\
\text { ILS, PPP, regulation, } \\
\text { LCC, PM (LCC and } \\
\text { availability) }\end{array}$ & $\begin{array}{l}\text { A processes modelling } \\
\text { consists nine stages: } \\
\text { Design, feasibility, } \\
\text { definition, development, }\end{array}$ & $\begin{array}{l}\text { AOP, AMF, } \\
\text { competency and } \\
\text { governance }\end{array}$ \\
\hline
\end{tabular}




\begin{tabular}{|c|c|c|c|c|c|}
\hline Author, year, title & Research Problem & Data Collection & $\begin{array}{c}\text { Critical Success Factors } \\
\text { in Acquisition }\end{array}$ & Research Output & $\begin{array}{l}\text { Areas not } \\
\text { Addressed }\end{array}$ \\
\hline $\begin{array}{l}\text { Materials of the Brazilian Air } \\
\text { Force }\end{array}$ & $\begin{array}{l}\text { the lifecycle of } \\
\text { systems and material. }\end{array}$ & & & $\begin{array}{l}\text { production, deployment, } \\
\text { use, revitalization, and } \\
\text { deactivation }\end{array}$ & \\
\hline $\begin{array}{l}\text { Humphries and Wilding } \\
\text { (2004) } \\
\text { Title: Sustained monopolistic } \\
\text { business relationships. A UK } \\
\text { defence procurement case. }\end{array}$ & $\begin{array}{l}\text { Business-to-business } \\
\text { Relationships } \\
\text { monopoly of supply } \\
\text { or demand. }\end{array}$ & $\begin{array}{l}\text { Triangulation. } \\
\text { questionnaire } \\
\text { survey a five-point } \\
\text { Likert scale) \& } \\
\text { qualitative } \\
\text { (semi-structure } \\
\text { interview) in MoD, } \\
\text { UK and industry. }\end{array}$ & $\begin{array}{l}\text { PPP, regulation, } \mathrm{PM} \\
\text { (value for money) }\end{array}$ & $\begin{array}{l}\text { An approach to solving } \\
\text { this problem thru } \\
\text { Co-operation, co- } \\
\text { ordination and } \\
\text { collaboration (C3 } \\
\text { behaviour) }\end{array}$ & $\begin{array}{l}\text { ILS, AOP, cost, } \\
\text { AMF, } \\
\text { competency and } \\
\text { governance. }\end{array}$ \\
\hline $\begin{array}{l}\text { Woodford and Smith (1998) } \\
\text { Title: The Minimization of } \\
\text { Combat Aircraft Life Cycle } \\
\text { Costs Through Conceptual } \\
\text { Design Optimization }\end{array}$ & $\begin{array}{l}\text { Procurement of more } \\
\text { cost-effective } \\
\text { military equipment. }\end{array}$ & $\begin{array}{l}\text {-Literature review. } \\
\text { Conceptual Design } \\
\text { Optimization }\end{array}$ & $\begin{array}{l}\text { ILS (limited to LCC), } \\
\text { LCC, PM (LCCt) }\end{array}$ & $\begin{array}{l}\text { Conceptual design } \\
\text { optimization has } \\
\text { minimized of combat } \\
\text { aircraft life cycle costs. } \\
\text { twin to single-engine } \\
\text { aircraft designed for } \\
\text { the same mission and } \\
\text { constraints. }\end{array}$ & $\begin{array}{l}\text { PPP, regulation, } \\
\text { AOP, AMF, } \\
\text { competency and } \\
\text { governance }\end{array}$ \\
\hline $\begin{array}{l}\text { Graham and } \\
\text { Hardaker (1998) } \\
\text { Title: Defence sector } \\
\text { procurement and } \\
\text { supply chain } \\
\text { relationships (MoD UK). }\end{array}$ & $\begin{array}{l}\text { To link the } \\
\text { competitive } \\
\text { performance of } \\
\text { small, high } \\
\text { technology defence } \\
\text { firms to their ability } \\
\text { to adapt to changes in } \\
\text { the procurement } \\
\text { process }\end{array}$ & $\begin{array}{l}\text {-Qualitative and } \\
\text { quantitative, case } \\
\text { studies: Survey on } \\
150 \text { firms by post } \\
\text { and telephone, } 40 \\
\text { interviews, } \\
\text { observation }\end{array}$ & $\begin{array}{l}\text { PPP, cost, PM (The } \\
\text { percentage success } \\
\text { rate of tendering for } \\
\text { defence sub-contract } \\
\text { work), AMF }\end{array}$ & $\begin{array}{l}\text { Strategic management } \\
\text { framework which } \\
\text { suggests a close } \\
\text { relationship between } \\
\text { industry structure, } \\
\text { strategy and performance. }\end{array}$ & $\begin{array}{l}\text { ILS, regulation, } \\
\text { AOP, } \\
\text { competency and } \\
\text { governance }\end{array}$ \\
\hline $\begin{array}{l}\text { Beesly (1966) Title: Some } \\
\text { Aspects of Military Aircraft } \\
\text { Procurement }\end{array}$ & $\begin{array}{l}\text { Current procurement } \\
\text { Procedures } \\
\text { improvements } \\
\text { For production } \\
\text { methods }\end{array}$ & $\begin{array}{l}\text {-Literature } \\
\text {-Observation }\end{array}$ & $\begin{array}{l}\text { PPP, regulation, cost, } \\
\text { PM }\end{array}$ & $\begin{array}{l}\text { Combined effort } \\
\text { government and industry. } \\
\text { Consider money spend on } \\
\text { aircraft research, design } \\
\text { and development. }\end{array}$ & $\begin{array}{l}\text { ILS, AOP, } \\
\text { AMF, } \\
\text { competency and } \\
\text { governance }\end{array}$ \\
\hline $\begin{array}{l}\text { Delano (1999) Title: Critical } \\
\text { success factors for DoD } \\
\text { program managers. }\end{array}$ & $\begin{array}{l}\text { DoD acquisition } \\
\text { programs frequently } \\
\text { face cost overruns, } \\
\text { poor performance, } \\
\text { schedule delays or } \\
\text { cancellation. }\end{array}$ & $\begin{array}{l}\text { Literature review } \\
\text { and survey ( } 21 \\
\text { respondents). }\end{array}$ & $\begin{array}{l}\text { Explicit requirements, } \\
\text { PPP, total quality, } \\
\text { stability e.g. no rapid } \\
\text { changes in budget etc., } \\
\text { performance objectives } \\
\text { (PM), cost objectives } \\
\text { (LCC), meet operational } \\
\text { capability date (Timely } \\
\text { AMF), work well (av), } \\
\text { adequate manpower, } \\
\text { competency and good } \\
\text { governance. }\end{array}$ & $\begin{array}{l}\text { CSFs consist of: } \\
\text { 1. Acquisition Factors - } \\
\text { well defined } \\
\text { requirements, strategy, } \\
\text { works well when in } \\
\text { service and stability } \\
\text { 2. Resource Factors - } \\
\text { competent and quality } \\
\text { people at all level (good } \\
\text { governance) }\end{array}$ & $\begin{array}{l}\text { ILS, regulations. } \\
\text { AOP }\end{array}$ \\
\hline $\begin{array}{l}\text { Ayhan and Üstüner (2015) } \\
\text { Title: Governance in public } \\
\text { procurement: the reform of } \\
\text { Turkey's public procurement }\end{array}$ & $\begin{array}{l}\text { Good governance in } \\
\text { Turkey public } \\
\text { procurement are hard } \\
\text { to sustain }\end{array}$ & $\begin{array}{l}\text { Case study-analysis } \\
\text { of the Turkish } \\
\text { public procurement } \\
\text {-Literature review } \\
\text {-Archival }\end{array}$ & $\begin{array}{l}\text { PPP, regulations, PM } \\
\text { (Level of good } \\
\text { governance), } \\
\text { governance. Limited } \\
\text { discussion on cost. }\end{array}$ & $\begin{array}{l}\text { Implementation of good } \\
\text { governance as part of } \\
\text { practice }\end{array}$ & $\begin{array}{l}\text { ILS, AOP, } \\
\text { AMF, } \\
\text { competency }\end{array}$ \\
\hline $\begin{array}{l}\text { Ribeiro and Furtado (2014) } \\
\text { Title: Government } \\
\text { Procurement Policy in } \\
\text { Developing } \\
\text { Countries: The Case of } \\
\text { Petrobras }\end{array}$ & $\begin{array}{l}\text { Promote innovation } \\
\text { by firms located in } \\
\text { developing countries }\end{array}$ & $\begin{array}{l}\text {-Literature } \\
\text {-Case Study: field } \\
\text { research interview } \\
\text { semi-structured } \\
\text { questionnaires }\end{array}$ & $\begin{array}{l}\text { PPP and PM - Level of } \\
\text { technological } \\
\text { learning/ innovativeness } \\
\text { (assume) }\end{array}$ & $\begin{array}{l}\text { Government Procurement } \\
\text { Policy stimulates } \\
\text { innovation by firms } \\
\text { located in developing } \\
\text { countries. }\end{array}$ & $\begin{array}{l}\text { ILS, regulation, } \\
\text { AOP, cost, } \\
\text { AMF, } \\
\text { competency and } \\
\text { governance }\end{array}$ \\
\hline $\begin{array}{l}\text { Mohammad Reza } \\
\text { Mohammadi (2013) } \\
\text { Title: Ranking of Critical } \\
\text { Success Factors of } \\
\text { e-procurement in Iranian } \\
\text { Automotive Industry }\end{array}$ & $\begin{array}{l}\text { Any communications } \\
\text { business needs to } \\
\text { reduce cost, and } \\
\text { time, increasing } \\
\text { accuracy, speed and } \\
\text { transparency as well } \\
\text { as reducing time and } \\
\text { financial costs }\end{array}$ & $\begin{array}{l}35 \text { researches } \\
\text { related to CFSs was } \\
\text { investigated. CSFs } \\
\text { selected based on } \\
\text { the frequency in the } \\
\text { literature }\end{array}$ & $\begin{array}{l}\text { Top management } \\
\text { commitment, security, } \\
\text { process, supplier } \\
\text { supporting, IT } \\
\text { infrastructure and } \\
\text { trained and skilful } \\
\text { employees }\end{array}$ & $\begin{array}{l}\text { CSFs in car } \\
\text { manufacturing industry of } \\
\text { Iran: Top management } \\
\text { commitment, security, } \\
\text { process, supplier } \\
\text { supporting, IT } \\
\text { infrastructure and } \\
\text { competent employees }\end{array}$ & $\begin{array}{l}\text { Regulations, } \\
\text { AMF, good } \\
\text { governance }\end{array}$ \\
\hline $\begin{array}{l}\text { Hui et al. }(2011) \\
\text { Title: Procurement issues in } \\
\text { Malaysia }\end{array}$ & $\begin{array}{l}\text { Issues such as } \\
\text { accountability } \\
\text { transparency, } \\
\text { corruption, integrity } \\
\text { and cronyism } \\
\text { pertaining to the }\end{array}$ & $\begin{array}{l}\text { Interviews - Six } \\
\text { main themes }\end{array}$ & $\begin{array}{l}\text { PPP, regulation, cost, } \\
\text { and performance } \\
\text { measure }\end{array}$ & $\begin{array}{l}\text { Required improvement. } \\
\text { Interference from } \\
\text { outside parties, cronyism, } \\
\text { malpractice and } \\
\text { non-compliance to the } \\
\text { policies }\end{array}$ & ILS, AOP, AMF \\
\hline
\end{tabular}




\begin{tabular}{|c|c|c|c|c|c|}
\hline Author, year, title & Research Problem & Data Collection & $\begin{array}{c}\text { Critical Success Factors } \\
\text { in Acquisition }\end{array}$ & Research Output & $\begin{array}{l}\text { Areas not } \\
\text { Addressed }\end{array}$ \\
\hline & $\begin{array}{l}\text { public procurement } \\
\text { system in Malaysia. }\end{array}$ & & & & \\
\hline $\begin{array}{l}\text { Rong et al. (2010) } \\
\text { Title: Acquisition strategy of } \\
\text { complicated equipment } \\
\text { based on optimization theory }\end{array}$ & $\begin{array}{l}\text { The problem of high } \\
\text { equipment } \\
\text { acquisition risk and } \\
\text { cost }\end{array}$ & $\begin{array}{l}\text {-Literature review. } \\
\text {-Archival }\end{array}$ & AOP, competency & $\begin{array}{l}\text { Mathematical Model } \\
\text { (QUAN) }\end{array}$ & $\begin{array}{l}\text { ILS, PPP, } \\
\text { regulation, cost, } \\
\text { PM, and AMF }\end{array}$ \\
\hline $\begin{array}{l}\text { Cheung et al. (2010) } \\
\text { Title: Suitability of procuring } \\
\text { large public works by PPP in } \\
\text { Hong Kong }\end{array}$ & $\begin{array}{l}\text { PPP has increasingly } \\
\text { been suggested in } \\
\text { projects, but the } \\
\text { suitability of using } \\
\text { this procurement } \\
\text { method in Hong } \\
\text { Kong is yet to be } \\
\text { studied empirically. } \\
\text { Delay } \\
\text { due to politics debate } \\
\text { and length delay for } \\
\text { Negotiation }\end{array}$ & $\begin{array}{l}\text { Questionnaire } \\
\text { survey }\end{array}$ & PPP, PM, competency & $\begin{array}{l}\text { The attractive factors to } \\
\text { work in PPP were scored } \\
\text { higher than the negative } \\
\text { factors }\end{array}$ & $\begin{array}{l}\text { ILS, regulation, } \\
\text { AOP, cost, AMF }\end{array}$ \\
\hline $\begin{array}{l}\text { Raymond (2008) } \\
\text { Title: Benchmarking in public } \\
\text { procurement. }\end{array}$ & $\begin{array}{l}\text { Poor procurement } \\
\text { practices hinder } \\
\text { sustainable } \\
\text { development and } \\
\text { negatively impact } \\
\text { upon economic } \\
\text { growth in developing } \\
\text { countries }\end{array}$ & $\begin{array}{l}\text { Using } \\
\text { benchmarking in } \\
\text { procurement } \\
\text { process and } \\
\text { perceived } \\
\text { weaknesses. } \\
\text { - Literature review } \\
\text {-Case Study - Sri } \\
\text { Lanka Public } \\
\text { Sector }\end{array}$ & $\begin{array}{l}\text { PM (Value for money, } \\
\text { professional } \\
\text { work force, ethics, } \\
\text { accountability, } \\
\text { transparency), attitude. }\end{array}$ & $\begin{array}{l}\text { Framework } \\
\text { Must include measures to } \\
\text { address issue of } \\
\text { accountability, } \\
\text { transparency, value for } \\
\text { money, professional } \\
\text { workforce and ethics. } \\
\text { These to overcome } \\
\text { weaknesses in the public } \\
\text { procurement process and } \\
\text { effective measurement. }\end{array}$ & $\begin{array}{l}\text { ILS, PPP, } \\
\text { regulation, AOP, } \\
\text { cost, AMF }\end{array}$ \\
\hline $\begin{array}{l}\text { Gregory (1992) } \\
\text { Title: Impact of life cycle cost } \\
\text { on procurement }\end{array}$ & $\begin{array}{l}\text { Historically, major } \\
\text { Procurement } \\
\text { decisions }\end{array}$ & -Literature review. & $\begin{array}{l}\text { Limited discussion on } \\
\text { ILS, PPP, LCC and PM }\end{array}$ & $\begin{array}{l}\text { Implementing Overall } \\
\text { Life Cycle Costs } \\
\text { Calculation }\end{array}$ & $\begin{array}{l}\text { Regulation, } \\
\text { AOP, AMF }\end{array}$ \\
\hline Decisions & $\begin{array}{l}\text { were made solely on } \\
\text { the basis of } \\
\text { performance and } \\
\text { acquisition cost } \\
\text { comparisons. }\end{array}$ & & & & \\
\hline
\end{tabular}

Note. ILS = Integrated Logistics Support, PPP = Public-Private Participation, Reg $=$ Regulation, AOP $=$ Acquisition Operational Process, AMF $=$ Acquisition Management Framework, SCM $=$ Supply Chain Management, Eng reqt. $=$ Engineering requirement, $\mathrm{LCC}=$ Life cycle cost

The literature review highlights 9 CSFs in acquisition which consist of integrated logistics support (ILS), public-private participation (PPP), regulations and policy, acquisition management framework (AMF), acquisition operational process (AOP), performance measure (PM), life cycle cost (LCC), competency of personnel, and good governance. In addition, the literature reviewed highlighted 19 elements associated to acquisition which consist of performance based logistics (PBL), Safety \& reliability centered maintenance (Safety \& RCM), failure mode, effect and criticality analysis (FMECA), logistics support analysis (LSA), logistics support analysis record (LSAR), computer aided logistics support (CALS), reliability, availability and maintainability (RAM), TLCS, level of repair analysis (LORA). In parallel, acquisition also requires effective maintenance planning, technical data, manpower and personal, supply support, support \& test equipment, computer resource support, facility, packaging handling storage and transportation (PHS\&T) e.g. NATO standards, design interface and binding contracts. Furthermore, all agreements associated to acquisition have to be in the form of binding contracts. These CSFs have been practiced by DoD USA, MoD UK and ADF with differences in terms of in-house processes. Nevertheless, DoD USA, MoD UK and ADF use almost similar CSFs and elements associated to acquisition. This research plans to use these CSFs and elements associated to acquisition to develop its preliminary ACF I. Table 3 shows 9 CSFs and 19 elements associated to acquisition as suggested from the literature.

Table 3. 9 CSFs and 19 elements associated to acquisition suggested from literature

\begin{tabular}{ll}
\hline $\begin{array}{c}\text { CSFs and Elements } \\
\text { Associated to Acquisition }\end{array}$ & Discussion \\
\hline$\underline{\text { I. ILS }}$ & $\begin{array}{l}\text { MoD UK, JSP } 886 \text { (2014) instructions for ILS implementation in acquisition is similar to DoD USA consist of: ILS planning, } \\
\text { maintenance planning, supply support, support and test equipment, facilities and infrastructure, training and training equipment, } \\
\text { technical information, PHS\&T, human factors integration, RAM, disposal and termination. }\end{array}$ \\
\hline$\underline{\text { element (DoD }}$ &
\end{tabular}


Maintenance planning Umar Al-Turki, (2011) defines maintenance planning as activities to maintain required availability and reliability of system and component to operate at standard quality. e.g. activities in maintenance concept, first line (OLM), second line (ILM), third line (DLM), MRO etc. or description of the requirements and tasks to be accomplished for achieving, restoring, or maintaining the operational capability of a system, equipment, or facility.

\begin{tabular}{ll}
\hline Technical data & $\begin{array}{l}\text { According to MoD UK, JSP } 886 \text { (2014), technical data consist the information require to operate, maintain, repair, support and } \\
\text { dispose of any equipment throughout its life cycle e.g. engine data, airframe hours, propeller hours, illustrated part catalogue etc. }\end{array}$ \\
\hline Manpower \& personal & e.g. adequacy human resource at all level, project team, field service representative (OEM) etc. \\
\hline Supply support & e.g. Spare parts, paint, oil, lubricant etc. \\
\hline Support and test & Support equipment i.e. ground support vehicle, ground support equipment, vibration test set etc.
\end{tabular}

equipment

2. Training

(competency) \&

training support

To achieve certain level of knowledge. Terry et al. (2007) once highlighted that aircraft quality assurance need to have wide variety of functional disciplines expertise. According to Delano (1999), well-educated and highly competent personnel are importance for successful acquisition e.g. competency, innovation, computer based training etc.

Computer resource It includes the facilities, hardware, software, documentation, manpower, and personnel require to operate and support systems related

support to equipment e.g. central processor input output module (CPIOM) software for A400M aircraft, computerize maintenance management system, on-line technical support etc.

Facility e.g. hangar, engine bay, hydraulic bay etc.

PHS \& T MoD UK, JSP 886 (2014) defines PHS \& T as the resources, procedures, design and methods in ensuring all products are packaged, handled, stored and transported properly in accordance with standard, legislation, particularly for hazardous items e.g. packaging in accordance with NATO standard etc.

Design interface $\quad$ Fielding (1980) highlighted on the importance of designer and operator to exchange data and work together to improve reliability e.g. possibility of involvement in design development under offset program etc.

\begin{tabular}{|c|c|}
\hline \multicolumn{2}{|c|}{ ILS Ten Supporting Element } \\
\hline LSA & $\begin{array}{l}\text { to define, analyze, and quantify logistics support requirements. According to JSP } 886 \text { (2014) LSA functions is to identify the optimum } \\
\text { support resource requirements for the whole life cycle of equipment. }\end{array}$ \\
\hline LSAR & Is record/documentations for LSA kept for future reference \\
\hline CALS & Computer aided acquisition and logistics support e.g. software and hardware for spare parts provisioning etc. \\
\hline RAM & $\begin{array}{l}\text { Reliability is the ability of item to perform a required function under stated condition for certain period of time i.e. Calculation of } \\
\text { components mean time between failure. Fielding (1980) suggested the establishment of a National Aerospace Reliability Data Bank in } \\
\text { UK. } \\
\text { Availability is system/product ready for task. } \\
\text { Maintainability: According to Pryor and M.B.E. (1964) deviation from reliability/unserviceable items require economy } \\
\text { maintainability in order to put it back to available condition. }\end{array}$ \\
\hline FMECA & $\begin{array}{l}\text { Failure, modes is the way or mode in which aircraft/component might fail, effects, and criticality analysis i.e. records of propeller over } \\
\text { speed, effect and criticality. Effect and criticality analysis is studying on the consequences of failure. }\end{array}$ \\
\hline TLCS & Product support throughout life cycle \& safety in all aspects i.e. provisioning for spare parts. \\
\hline LORA & Level of repair analysis i.e. in-situ repair, second line servicing, third line - overhaul etc. \\
\hline 3. LCC & $\begin{array}{l}\text { is cost implications i.e. acquisition cost, in-service cost, disposal cost. Sokri (2014) defined LCC as an economic assessment that } \\
\text { includes the operation and maintenance cost of systems over its life cycle. Case study Canadian Arcturus fleet, the results show that } \\
\text { operation and maintenance costs approximately } 70.81 \% \text { of the overall life cycle cost. DoD USA also focus on LCC as instructed in } \\
\text { Directive 5000.1- the Defence Acquisition System, and Instruction } 5000.2 \text { - Operation of the Defence Acquisition System. }\end{array}$ \\
\hline $\mathrm{RCM}$ & $\begin{array}{l}\text { A process in analyzing the functions and potential failures for aircraft/component. Mishra (2016) suggested the implementation of } \\
\mathrm{RCM} \text { by weighing all opportunities and threats for strategic decision. }\end{array}$ \\
\hline PBL & $\begin{array}{l}\text { One of performance measure. Other performance measure i.e. direct measurement, turn-around time repair etc. According to Glas et } \\
\text { al. (2013), problem in increasing support cost for complex system i.e. aircraft can be addressed through PBL. }\end{array}$ \\
\hline 4. PPP & $\begin{array}{l}\text { Ecosystem for public-private participation in aerospace defence industry e.g. ToT in offset program is agreement that exporter to } \\
\text { ensure ToT and undertake activities in order to satisfy the importer requirements (Ianakiev, 2014). Alinaitwe and Ayesiga (2013) in } \\
\text { case study in the construction industry in Uganda highlighted, successful PPP implementation require a competitive procurement } \\
\text { process, a well organised private sector, competent personnel and good governance. In acquisition, DoD USA policy encourages early } \\
\text { industry involvement (Federal Advisory Committee Act (FACA) and FAR Part 15). Beaugency et al. (2015) studied different } \\
\text { approaches on PPP. Case study on Airbus not outsourcing the development and production of flight control systems contrary to } \\
\text { Boeing that work together with other vendors. The main objectives for both is cost reduction. }\end{array}$ \\
\hline 5. AMF & $\begin{array}{l}\text { Explicit acquisition management framework with process and specific timeframe. Bowen (1996) in case study of RAAF Orion aircraft } \\
\text { maintenance has proposed total quality management in maintenance, translated into a process, mapping, and measured to collect } \\
\text { valuable data. Samaranayake et al. (2002) proposes effective control of project management and predict spare parts requirement to } \\
\text { minimise aircraft downtime. According to Schwartz (2013), a milestone in acquisition management (DODI 5000.02, 2015) is required } \\
\text { to oversee and manage acquisition programs. At each process, a program must meet specific DoD USA requirements before can } \\
\text { proceed to the next phase of acquisition process. }\end{array}$ \\
\hline 6. AOP & $\begin{array}{l}\text { Explicit acquisition operational process. Worger et al. (2014) mentioned that, AOP would help reduce program development delays } \\
\text { and cost overrun. At each acquisition process (AOP) it must meet DoD USA requirements before proceed to next acquisition process } \\
\text { (Schwartz (2013) }\end{array}$ \\
\hline 7. Regulation \& policy & $\begin{array}{l}\text { Supporting regulation and policy in acquisition. According to Worger et al. (2014) supporting policy can improve DoD' complex } \\
\text { acquisition process. }\end{array}$ \\
\hline
\end{tabular}




\begin{tabular}{ll}
\hline $\begin{array}{l}\text { 8. Performance } \\
\text { measure }\end{array}$ & $\begin{array}{l}\text { To measure achievement. According to Kevin et al. (2014) measuring a company's performance help an organization to achieve and } \\
\text { maintain success. Parida et al. (2015) mentioned that, measurement of maintenance output and its quality are required to justify } \\
\text { investment. DoD Defence Acquisition Guide Book (2013) highlighted, the acquisition strategy should include a performance-based } \\
\text { business strategy. }\end{array}$ \\
\hline 9. Good governance & $\begin{array}{l}\text { Manage with good ethics. According to Alinaitwe and Ayesiga (2013) one of CSF in PPP is good governance. Ayhan and Üstüner } \\
\text { (2015) in case study Turkish public procurement, highlighted about the importance of implementation of good governance as part of } \\
\text { practice. In line with Juanita et al. (2016), highlighted the fraud incidents in DoD USA procurement which generally happen during } \\
\text { source selection, contract management phases, control activities and this issue need to be addressed. }\end{array}$ \\
\hline Binding contract & $\begin{array}{l}\text { Acquisition agreement in a binding contract and performance measure as an integrated performance measurement to optimize weapon } \\
\text { systems Av i.e. contract with OEM for A400M using availability as performance measure. Type of contract e.g., firm fixed-price } \\
\text { (FFP), fixed-price incentive etc. (DoD Defence Acquisition Guide Book, 2013) }\end{array}$ \\
\hline
\end{tabular}

Legend:

$\square$ CSFs in acquisition $\square$ 19 elements associated to acquisition

\subsection{The Hypotheses and Their Correspondence to Research Design}

Three Questions (Q) were put forward: Q1. Why has the RMAF not achieve its aircraft Av as its desired objectives? Q2: How do the RMAF's present acquisition practices given significant impact to aircraft Av? Q3: What is the recommended ACF to be used to ensure higher aircraft Av? In answering these questions, the mix mode method (Quantitative and Qualitative) data collection was used. A research using the mix mode method data collection has more confident results and enriched explanation of the research problem by combining qualitative and quantitative research methods (Starr, 2014; Aldebert \& Rouzies, 2014; Bhattacherjee, 2012; Tashakkori \& Teddlie, 2010; Salehi \& Golafshani, 2010).

\section{Methodology}

This chapter will describe the overall research methodology. Research methodology is the process to collect information and data for analysis. It includes publication research, interview, surveys, experiments, observation and others. According to Khotari (2005), research methodology is a way to solve the research problem systematically or the science of studying how the research is done. The research methodology is divided into ten steps. The research methodology used was modified and adopted from the works of Durugbo and Erkoyuncu (2016); Caldwell and Howard, (2014); Jefferies et al. (2014); Starr (2014); Davids et al. (2013); Glas, Hofmann and Eßig (2013); Cheung et al. (2012); Bowyer and Davis (2012); Burgess and Balakrishnan, (2014); Eßig et al. (2014); Aguado-Romero et al. (2013); Abd Rahman Abdul Rahim and Baskh (2003); Yin (1994).

\subsection{General Ideas of Research Methodology}

Figure 1 shows the general ideas of the research methodology which consists of six steps.

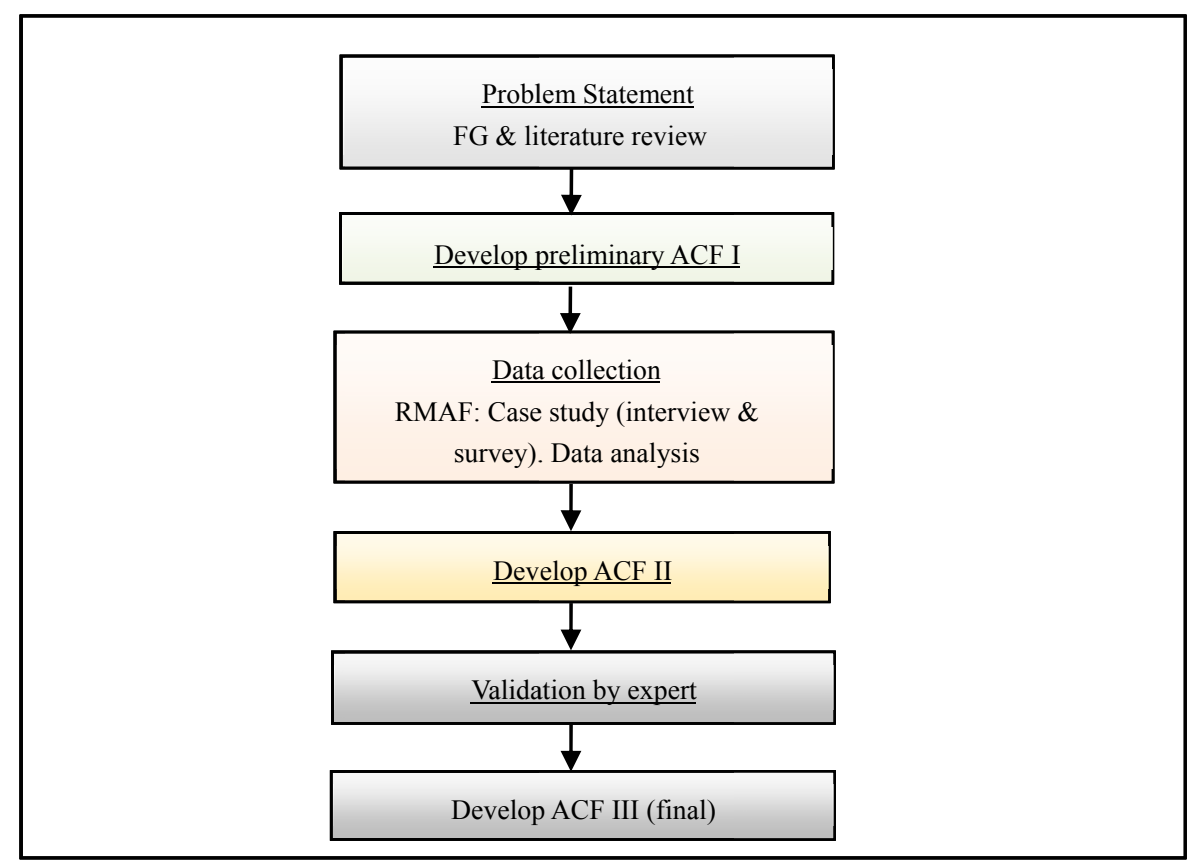

Figure 1. General ideas of research methodology

A focus group discussion is used as a head start for the research, followed by the literature review where the 
preliminary ACF 1 was developed. From the case study results, the preliminary ACF 1 was revised into ACF II. Then, ACF II was validated by experts and revised into ACF III as the final framework. Table 4 shows the general ideas of research question, research objective, data collection, data analysis and research output.

Table 4. Research question, research objective, data collection, data analysis and research output

\begin{tabular}{|c|c|c|c|c|c|}
\hline No & Research Question & Research Objective & Data Collection & Data Analysis & Research Output \\
\hline 1. & $\begin{array}{c}\text { Why has the RMAF not achieve its } \\
\text { aircraft Av as its desired } \\
\text { objectives? }\end{array}$ & $\begin{array}{l}\text { To identify the cause of low } \\
\text { aircraft availability in RMAF. }\end{array}$ & $\begin{array}{l}\text { Aircraft status } \\
\text { FY } 2011 \text { to } 2015\end{array}$ & $\begin{array}{l}\text { Percentage of } \\
\text { AWP, CONT } \\
\text { and IWRK }\end{array}$ & $\begin{array}{l}\text { Low Av as results of higher } \\
\text { aircraft downtime due to AWP } \\
\text { and CONT. }\end{array}$ \\
\hline 2. & $\begin{array}{l}\text { How do the RMAF's present } \\
\text { acquisition practices given } \\
\text { significant impact to aircraft Av? }\end{array}$ & $\begin{array}{l}\text { To identify the RMAF present } \\
\text { acquisition practices and its } \\
\text { significant impact to aircraft } \\
\text { availability }\end{array}$ & $\begin{array}{c}\text { Literature } \\
\text { Interview \& } \\
\text { survey }\end{array}$ & $\begin{array}{l}\text { Themes, coding, } \\
\text { category and sub } \\
\text { category }\end{array}$ & $\begin{array}{c}\text { Ineffective and inefficient } \\
\text { acquisition practices which was } \\
\text { based on ad hoc basis. }\end{array}$ \\
\hline 3. & $\begin{array}{l}\text { What is the recommended ACF to } \\
\text { be used to ensure higher aircraft } \\
\text { Av? }\end{array}$ & $\begin{array}{l}\text { To propose the Acquisition } \\
\text { Conceptual Framework for } \\
\text { aircraft acquisition in RMAF. }\end{array}$ & $\begin{array}{c}\text { Literature } \\
\text { Interview \& } \\
\text { survey }\end{array}$ & $\begin{array}{c}\text { Themes, } \\
\text { Themes, coding, } \\
\text { category and sub } \\
\text { category }\end{array}$ & $\begin{array}{l}\text { ACF III (final) was developed } \\
\text { based on CSFs and elements } \\
\text { associated to acquisition. }\end{array}$ \\
\hline
\end{tabular}

\subsection{A step-by-step Methodology Process}

A step-by-step methodology process was shown in Figure 2.

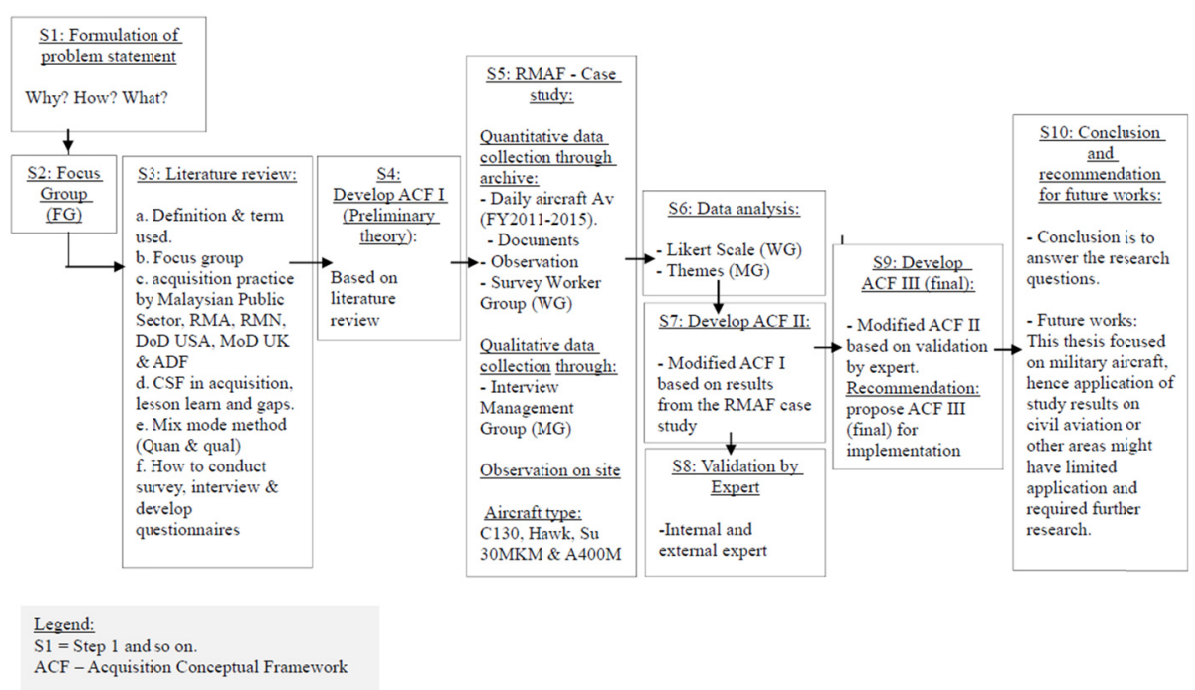

Figure 2. Flow process for research methodology

Figure 2 shows the research methodology which is divided into ten steps. A step-by-step methodology process is shown in the following.

Step 1 (S1): Formulation of problem statement. This section discussed the problem faced by the RMAF by focusing on aircraft availability. Why has the RMAF not achieved aircraft availability as per its desired objectives? How do the RMAF's present acquisition practices give a significant impact on aircraft availability? What is the recommended acquisition conceptual framework to be used to ensure high aircraft availability?

Step 2 (S2): Focus group. This research started with a discussion with a focus group (Starr, 2014) which consists of eight senior officers led by a moderator (Salant and Dillman, 1994) and supported by observation of actual practices in the field (Starr, 2014; Abd Rahman Abdul Rahim and Baskh, 2003).

Step 3 (S3): Literature review. Literature review was conducted with the purpose:

a. To determine the critical success factors in acquisition and the research gaps.

b. To carry out discussion with a focus group.

c. To conduct a case study on the RMAF through survey, interviews and participant observation.

d. To identify the lessons learnt on acquisition practices in the Malaysian public service, the Royal Malaysian Army and Navy, the DoD USA, the MoD UK and the Australian Defence Forces.

Step 4 (S4): Develop preliminary ACF I. Observation on the field and literature review were used to develop ACF I.

Step 5 (S5): Case study on the RMAF. The Type A, Type B, Type C, and Type D aircraft were chosen as case 
studies to identify the lessons learnt, weaknesses and good practices. The research adopted the mixed mode method to collect quantitative and qualitative data (Starr, 2014; Davids, et al., 2013). Data collection was carried out using daily aircraft availability status taken from 2011 to 2015 along with other documentation such as regulations, directives, policies, procedures, and related publications available at the MoD library and observation of actual practices in the field (Glas et al., 2013; Cheung et al., (2012). This research employs a survey questionnaire for the worker group with ordered choices. Qualitative data collection from the management group was done through face-to-face interviews using semi-structured and open ended questionnaires (Bowyer and Davis, 2012). According to Burgess and Balakrishnan (2014) and Davids et al (2013), face-to-face interviews yield more precise answers than other techniques. The management group respondents were given a copy of the preliminary ACF I two days earlier (before the interview took place) to ensure that they have ample time to read. Respondents from the management group were asked to answer a questionnaire on the relevancy of the preliminary ACF I developed in step 4 in order to solicit suggestions for further improvement. Responses from the worker group and management group were recorded for analysis and presented in the matrix table.

Step 6 (S6): Data analysis: The Likert Scale was used to analyse the quantitative data obtained from the worker group. As for the management group, the interview recorded themes for analysis. Data analysis is shown in the next section.

Step 7 (S7): Modification of preliminary ACF I and development of ACF II (Cheung et al., 2012; Rutner et al., 2012; Abd Rahman Abdul Rahim and Baskh, 2003); and Yin, 1994) which was based on the results from data analysis and input from the case studies.

Step 8 (S8): Validation by experts. The modified ACF II was validated by two senior officers in the RMAF and two Senior Managers from Airod Technopower Sdn Bhd. Letters to invite the experts' validation were sent to these four validators.

Step 9 (S9): Develop ACF III (final): ACF II was modified based on input from experts and ACF III was proposed for implementation. This section proposes the final ACF III which integrates all critical success factors in acquisition for the implementation, while also giving some recommendations for further improvement.

Step 10 (S10): Conclusion and recommendation for future work. This section is primarily to answer the problem statement which is "why" and "how" the aircraft in the RMAF fleet have yet to achieve and sustain at least $70 \%$ of availability (Av). Moreover, "what" is the recommended ACF which suits RMAF's requirements of ensuring higher aircraft Av? This paper focuses on military aircraft; hence the application of the study results on civil aviation or other areas might be limited and require further research.

\subsection{Participant Characteristics}

The surveys conducted on the WG had involved the RMAF's technical personnel ranging from the rank of Airmen to Warrant Officer, and the interviews with the MG involved officers ranked from Second Lieutenant to Brigadier General who had worked on the Type A, Type B, Type C, and Type D Aircraft.

\subsubsection{Sampling Procedures}

The research study adopted a group-administered survey (Bhattacherjie, 2012; Sekaran \& Bougie, 2009; Maxim, 1999) where the WG has to answer sixteen (16) semi-structured questionnaires which are closed-ended with all-points-anchored response options. Face-to-face interviews were conducted on twenty (20) out of twenty (20) respondents from the MG. They had to answer twenty-one (21) semi-structured questionnaires with open-ended answers. Then, five people from the pilot team of the WG and five people from the MG were selected for pretesting, validating and trying these questionnaires. Based on the comments from the pilot team, the questionnaires were amended before the actual survey was made. The Likert Scale (Likert, 1932) was used in this project as shown in Table 5 .

Table 5. The five points scale, closed-ended with all-points-anchored response options for the Worker Group

\begin{tabular}{clccc}
\hline Strongly Disagree (SD) & $\frac{\text { Disagree (D) }}{2}$ & $\frac{\text { Neutral (N) }}{3}$ & $\frac{\text { Agree (A) }}{4}$ & $\frac{\text { Atrongly Agree (SA) }}{(5)}$ \\
\hline 1 & $\frac{\text { Almost Never }}{2}$ & $\frac{\text { Neutral }}{3}$ & $\frac{\text { Most of the Time }}{4}$ & $\frac{\text { Always }}{5}$ \\
\hline
\end{tabular}

This study adopted the five-point scale with all-points-anchored response options (Chueng et al., 2010; Ellis, 1994; Likert, 1932) for the WG. The WG has to make a choice by circling the number 1 or 2 or 3 or 4 or 5 in the column that represents their feelings accorsing to its choice of either, "Strongly Agreed" (5), "Agree" (4), 
"Neutral" (3), "Disagrees" (2), "Strongly Disagreed" (1). These questionnaires also ask the respondents' feelings on their day-to-day work too, with the options of either, "Always" (5), "Most of the Time" (4), "Neutral" (3), "Almost Never" (2), "Never" (1). The results were recorded in a matrix table.

\subsubsection{Sample Size}

This research study adopted a sample size with a 95\% confidence level. There were twenty out of the twenty respondents from the MG (+-3\% estimated sampling error). Respondents from the WG numbered at 120 out of 150 respondents (+-5\% estimated sampling error) as suggested by Salant and Dillman (1994). The results are depicted in a table form. The research questions were answered with more than $70 \%$ response rate, exceeding the response rate recommended by Crotts et al. (2008), Janes (2001), and Maxim (1999). The survey time was 15 to 45 minutes (Janes, 2001).

\section{Results}

This section shows the results from the literature review, case study and validation process.

\subsection{Results from Literature Review}

There are the findings:

\subsubsection{Critical Success Factors in Acquisition}

The literature review highlighted 9 CSFs in acquisition and 19 elements associated to acquisition for this research to develop the preliminary ACF I as shown in Figure 3.

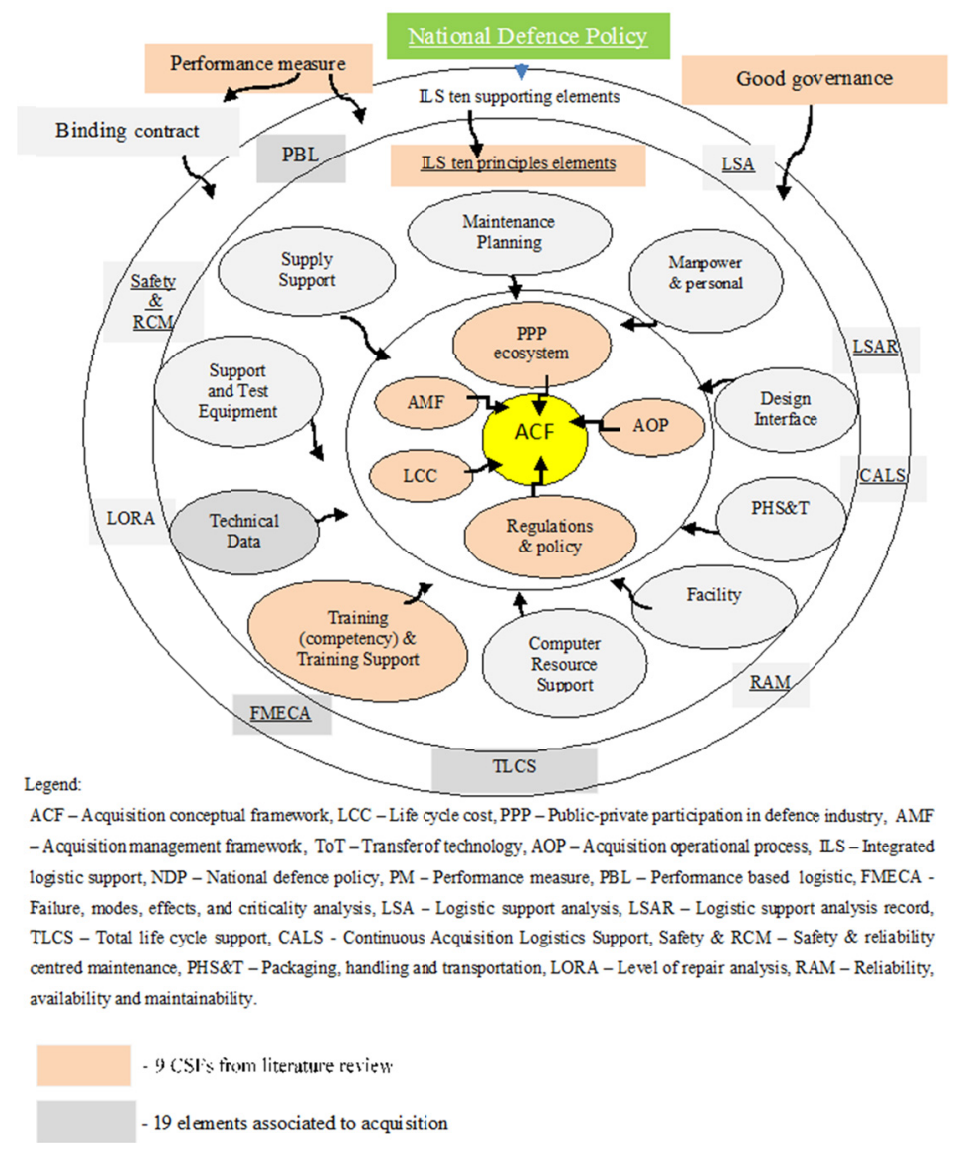

Figure 3. Preliminary acquisition conceptual framework (ACF I)

Figure 3 shows the preliminary ACF I that was developed using the 9 CSFs and 19 elements associated to acquisition obtained from the literature review and which was modified to ACF II based on the RMAF's case study result.

\subsubsection{Gaps in Literature}

The literature review conducted presented gaps where there still is an unclear acquisition framework which integrates the CSFs to suit the RMAF's unique requirement (e.g. require robust system for military concept of 
operations (CONOPS), all weather operations and etc) and is compatible to the local industry's capability. The acquisition frameworks used by the DoD USA, MoD UK, and ADF are not suitable for the RMAF because the Malaysian aviation industry still lags behind compared to those advance countries (Malaysia Defence Security Report Q4, 2011). Therefore, other frameworks are not suitable to the RMAF. In addition, integration among the 9 CSFs and 19 elements associated to acquisition in literature was unclear and is separately discussed in different topics. These are the knowledge gaps that this study hopes to fill. Preliminary finding from the focus group discussion, observation in the field and literature review found limited discussion of CSFs in acquisition, which is similar to the present practices in the Malaysian public sector, the RMA, and the RMN.

\subsection{Results from Case Study}

Based on the data collected from the RMAF ASHQ, the percentage of three aircraft's Av from year 2011 to 2015 (Type A, Type B, and Type C) is below the targeted 70\% Av. The aircraft downtime is because AWP is approximately $23 \%$ and CONT is approximately $25 \%$, which are higher than the targeted $\leq 10 \%$ for each downtime. Downtime due to IWRK is below $10 \%$ and is within the target limits. However, there was limited one year data available for Type D Aircraft with 90\% Av, 5\% AWP and 5\% IWRK, since it had recently entered into service in Jan 2015.

\subsubsection{Worker Group Survey Results}

This section shows the measurement category, questionnaire, survey results and average of the survey results for the WG. Answers with higher degrees of agreement are on the right-hand side of the matrix in Table 6 . Then, the results are summarized in Table 7.

Table 6. Showed the measurement category, questionnaires, survey results and average of the survey results for the Worker Group

\begin{tabular}{|c|c|c|c|c|c|c|}
\hline \multirow{3}{*}{$\begin{array}{l}\text { Measure } \\
\text { Category }\end{array}$} & \multirow[t]{2}{*}{ Questionnaires (Worker Group) } & \multicolumn{5}{|c|}{ RESULTS (\%) } \\
\hline & & $\begin{array}{l}\text { Strongly } \\
\text { disagreed } \\
\text { (a) }\end{array}$ & $\begin{array}{l}\text { Disagreed } \\
\text { (b) }\end{array}$ & $\begin{array}{l}\text { Neutral } \\
\text { (c ) }\end{array}$ & $\begin{array}{l}\text { Agreed } \\
\text { (d) }\end{array}$ & $\begin{array}{l}\text { Strongly } \\
\text { Agreed } \\
\text { (e) }\end{array}$ \\
\hline & $\begin{array}{l}\text { (The Answer with higher degree of agreement is on } \\
\text { the right-hand side) }\end{array}$ & (1) & (2) & (3) & (4) & (5) \\
\hline \multirow{10}{*}{$\begin{array}{l}\text { Cat 1: Effectiveness } \\
\text { (E) / Ineffectiveness } \\
\text { (IE) of ILS in RMAF } \\
\text { current practice }\end{array}$} & $\begin{array}{l}\text { Q1. I use more time looking for aircraft spares than I } \\
\text { work on aircraft troubleshooting. }\end{array}$ & $\begin{array}{c}1 \\
(0.83 \%) \\
\end{array}$ & $\begin{array}{c}1 \\
(0.83 \%) \\
\end{array}$ & $\begin{array}{c}1 \\
(0.83 \%) \\
\end{array}$ & $\begin{array}{c}22 \\
(18.33 \%) \\
\end{array}$ & $\begin{array}{c}95 \\
(79.16 \%) \\
\end{array}$ \\
\hline & $\begin{array}{l}\text { Q2. To what extent you agree, integrated logistics } \\
\text { support is not fully implemented at your workplace. }\end{array}$ & $\begin{array}{c}0 \\
(0 \%) \\
\end{array}$ & $\begin{array}{c}1 \\
(0.83 \%) \\
\end{array}$ & $\begin{array}{c}2 \\
(1.67 \%) \\
\end{array}$ & $\begin{array}{c}20 \\
(16.67 \%) \\
\end{array}$ & $\begin{array}{c}97 \\
(80.83 \%) \\
\end{array}$ \\
\hline & $\begin{array}{l}\text { Q3. To what extent you agree, logistics support needs } \\
\text { to be reorganized in order to ensure spares available } \\
\text { on time }\end{array}$ & $\begin{array}{c}0 \\
(0 \%)\end{array}$ & $\begin{array}{c}0 \\
(0 \%)\end{array}$ & $\begin{array}{c}2 \\
(1.67 \%)\end{array}$ & $\begin{array}{c}16 \\
(13.33 \%)\end{array}$ & $\begin{array}{c}102 \\
(85 \%)\end{array}$ \\
\hline & $\begin{array}{l}\text { Q4. To what extent you agree, logistics support needs } \\
\text { to be planned during aircraft acquisition. }\end{array}$ & $\begin{array}{c}0 \\
(0 \%)\end{array}$ & $\begin{array}{c}1 \\
(0.83 \%)\end{array}$ & $\begin{array}{c}6 \\
(5.0 \%) \\
\end{array}$ & $\begin{array}{c}28 \\
(23.33 \%) \\
\end{array}$ & $\begin{array}{c}85 \\
(70.83 \%) \\
\end{array}$ \\
\hline & $\begin{array}{l}\text { Q10. I cannot make aircraft serviceable on time due } \\
\text { to spares are not available on time. }\end{array}$ & $\begin{array}{c}0 \\
(0 \%) \\
\end{array}$ & $\begin{array}{c}0 \\
(0 \%) \\
\end{array}$ & $\begin{array}{c}0 \\
(0 \%) \\
\end{array}$ & $\begin{array}{c}2 \\
(1.67 \%) \\
\end{array}$ & $118(98.33 \%)$ \\
\hline & $\begin{array}{l}\text { When you think about your work, how often do you } \\
\text { experience the following: }\end{array}$ & Never & $\begin{array}{r}\text { Almost } \\
\text { Never }\end{array}$ & Neutral & $\begin{array}{l}\text { Most of } \\
\text { the Time }\end{array}$ & Always \\
\hline & Q14. Not to get spares on time. & $\begin{array}{c}0 \\
(0 \%) \\
\end{array}$ & $\begin{array}{c}0 \\
(0 \%) \\
\end{array}$ & $\begin{array}{c}2 \\
(1.67 \%) \\
\end{array}$ & $\begin{array}{c}19 \\
(15.83 \%) \\
\end{array}$ & $\begin{array}{c}99 \\
(82.5 \%) \\
\end{array}$ \\
\hline & $\begin{array}{l}\text { Q15. Wasted time in spares robbing (take spare part } \\
\text { from other similar type of aircraft). }\end{array}$ & $\begin{array}{c}0 \\
(0 \%)\end{array}$ & $\begin{array}{c}0 \\
(0 \%)\end{array}$ & $\begin{array}{c}1 \\
(0.83 \%)\end{array}$ & $\begin{array}{c}4 \\
(3.33 \%)\end{array}$ & $115(95.83 \%)$ \\
\hline & Q16. Need to hasten for spares. & $\begin{array}{c}1 \\
(0.83 \%) \\
\end{array}$ & $\begin{array}{c}1 \\
(0.83 \%) \\
\end{array}$ & $\begin{array}{c}2 \\
(1.67 \%) \\
\end{array}$ & $\begin{array}{c}30 \\
(25.0 \%) \\
\end{array}$ & $\begin{array}{c}86 \\
(71.66 \%) \\
\end{array}$ \\
\hline & AVERAGE & $0.25(0.21 \%)$ & $\begin{array}{c}0.5 \\
(0.42 \%)\end{array}$ & $\begin{array}{c}2 \\
(1.67 \%)\end{array}$ & $\begin{array}{c}17.625 \\
(14.69 \%)\end{array}$ & $\begin{array}{l}99.625 \\
(83 \%)\end{array}$ \\
\hline \multicolumn{7}{|c|}{ Note . Cat $=$ Category, $\mathrm{E}=$ Effectiveness, $\mathrm{IE}=$ Ineffectiveness, $\mathrm{Q}=$ Question. } \\
\hline \multirow{3}{*}{$\begin{array}{l}\text { Measure } \\
\text { Category }\end{array}$} & Questionnaires (Worker Group) & \multicolumn{5}{|c|}{ RESULTS (\%) } \\
\hline & & $\begin{array}{l}\text { Strongly } \\
\text { disagreed } \\
\text { (a) }\end{array}$ & $\begin{array}{l}\text { Disagreed } \\
\text { (b) }\end{array}$ & $\begin{array}{l}\text { Neutral } \\
\text { (c ) }\end{array}$ & Agreed & $\begin{array}{l}\text { Strongly } \\
\text { Agreed } \\
\text { (e) }\end{array}$ \\
\hline & $\begin{array}{l}\text { (The Answer with Higher Degree of agreement is on } \\
\text { the Right-Hand Side) }\end{array}$ & (1) & $(2)$ & (3) & (4) & $(5)$ \\
\hline \multirow{2}{*}{$\begin{array}{l}\text { Cat 2: Effectiveness/ } \\
\text { Ineffective of PPP } \\
\text { ecosystem in RMAF }\end{array}$} & $\begin{array}{l}\text { Q7. To what extent you agree that local industry need } \\
\text { to increase their support. }\end{array}$ & $\begin{array}{c}2 \\
(1.67 \%) \\
\end{array}$ & $\begin{array}{c}1 \\
0.83 \%)\end{array}$ & $\begin{array}{c}1 \\
(0.83 \%) \\
\end{array}$ & $\begin{array}{c}16 \\
(13.33 \%) \\
\end{array}$ & $\begin{array}{c}100 \\
(83.33 \%) \\
\end{array}$ \\
\hline & Q8. To what extent you agree that, the government & 2 & 2 & 2 & 21 & 93 \\
\hline
\end{tabular}




\begin{tabular}{|c|c|c|c|c|c|c|}
\hline \multirow{4}{*}{$\begin{array}{l}\text { aerospace defence } \\
\text { industry }\end{array}$} & \multirow[b]{2}{*}{ sectors need to increase their support. } & & & & & \multirow[b]{2}{*}{$(77.5 \%)$} \\
\hline & & $(1.67 \%)$ & $(1.67 \%)$ & $(1.67 \%)$ & $(17.5 \%)$ & \\
\hline & $\begin{array}{l}\text { Q11. To what extent you agree for the government } \\
\text { sectors to work together with industry in supporting } \\
\text { the aircraft maintenance }\end{array}$ & $\begin{array}{c}2 \\
(1.67 \%)\end{array}$ & $\begin{array}{c}2 \\
(1.67 \%)\end{array}$ & $\begin{array}{c}4 \\
(3.33 \%)\end{array}$ & $\begin{array}{c}22 \\
(18.33 \%)\end{array}$ & $\begin{array}{c}90 \\
(75 \%)\end{array}$ \\
\hline & $\begin{array}{l}\text { Q12. To what extent you agree for the industry to } \\
\text { increase their capability and specialty before } \\
\text { participating at your work place. }\end{array}$ & $\begin{array}{c}2 \\
(1.67 \%)\end{array}$ & $\begin{array}{c}2 \\
(1.67 \%)\end{array}$ & $\begin{array}{c}6 \\
(5.0 \%)\end{array}$ & $\begin{array}{c}22 \\
(18.33 \%)\end{array}$ & $\begin{array}{c}88 \\
(73.33 \%)\end{array}$ \\
\hline \multicolumn{2}{|l|}{$(d)+(e)=$} & $\begin{array}{c}2 \\
(1.67 \%)\end{array}$ & $\begin{array}{c}1.75 \\
(1.46 \%)\end{array}$ & $\begin{array}{c}3.25 \\
(2.71 \%)\end{array}$ & $\begin{array}{c}20 \\
(16.67 \%)\end{array}$ & $\begin{array}{c}93 \\
(77.5 \%) \\
\end{array}$ \\
\hline \multirow[t]{2}{*}{$\begin{array}{l}\text { Cat 3: Adequacy/ } \\
\text { inadequacy of } \\
\text { Regulation, Policy, } \\
\text { Proc }\end{array}$} & $\begin{array}{l}\text { Q5. To what extent you agree that, policy in } \\
\text { integrated logistics support is inadequate at your } \\
\text { workplace. }\end{array}$ & $\begin{array}{c}2 \\
(1.67 \%)\end{array}$ & $\begin{array}{c}2 \\
(1.67 \%)\end{array}$ & $15(12.5 \%)$ & $\begin{array}{c}11 \\
(9.17 \%)\end{array}$ & $\begin{array}{c}90 \\
(75 \%)\end{array}$ \\
\hline & $\begin{array}{l}\text { Q9. To what extent you agree that inadequacy of } \\
\text { guideline for industry and government sectors } \\
\text { participation in supporting your workplace. }\end{array}$ & $\begin{array}{c}2 \\
(1.67 \%)\end{array}$ & $\begin{array}{c}2 \\
(1.67 \%)\end{array}$ & $\begin{array}{c}12 \\
(10 \%)\end{array}$ & $\begin{array}{c}16 \\
(13.33 \%)\end{array}$ & $\begin{array}{c}88 \\
(73.33 \%)\end{array}$ \\
\hline \multicolumn{2}{|c|}{$(\mathrm{d})+(\mathrm{e})=\mathrm{IA}_{\mathrm{IAVERAGE}}$} & $\begin{array}{c}2 \\
(1.67 \%) \\
\end{array}$ & $\begin{array}{c}2 \\
(1.67 \%) \\
\end{array}$ & $\begin{array}{c}13.5 \\
(11.25 \%) \\
\end{array}$ & $\begin{array}{c}13.5 \\
(11.25 \%) \\
\end{array}$ & $\begin{array}{c}89 \\
(74.17 \%) \\
\end{array}$ \\
\hline $\begin{array}{l}\text { Cat 4: AMF, Cat 5: } \\
\text { AOP, Cat 6:PM and } \\
\text { Cat 7: LCC }\end{array}$ & $\begin{array}{l}\text { These categories were not measured which is beyond } \\
\text { WG responsibility }\end{array}$ & - & - & - & - & - \\
\hline \multirow[t]{2}{*}{$\begin{array}{l}\text { Cat 8: Competency of } \\
\text { Personnel }\end{array}$} & $\begin{array}{l}\text { Q6. For works I put in the acquisition process of any } \\
\text { RMAF equipment, I was trained to do that. }\end{array}$ & $\begin{array}{c}3 \\
(2.5 \%) \\
\end{array}$ & $\begin{array}{l}3 \\
(2.5 \%) \\
\end{array}$ & $\begin{array}{c}3 \\
(2.5 \%) \\
\end{array}$ & $\begin{array}{c}11 \\
(9.17 \%) \\
\end{array}$ & $\begin{array}{c}100 \\
(83.3 \%) \\
\end{array}$ \\
\hline & $\begin{array}{l}\text { Q13. If I involve in any RMAF acquisition; I was } \\
\text { trained to do the job }\end{array}$ & $\begin{array}{l}3 \\
(2.5 \%)\end{array}$ & $\begin{array}{c}2 \\
(1.67 \%)\end{array}$ & $\begin{array}{c}2 \\
(1.67 \%)\end{array}$ & $\begin{array}{c}11 \\
(9.17 \%)\end{array}$ & $\begin{array}{c}102 \\
(85 \%)\end{array}$ \\
\hline \multicolumn{2}{|c|}{$(\mathrm{d})+(\mathrm{e})=\mathrm{P}>93 \%$} & $\begin{array}{c}3 \\
(2.5 \%) \\
\end{array}$ & $2.5(2.08 \%)$ & $2.5(2.08 \%)$ & $\begin{array}{c}11 \\
(9.17 \%) \\
\end{array}$ & $101(84.17 \%)$ \\
\hline Cat 9: Governance & $\begin{array}{l}\text { These categories were not measured which is beyond } \\
\text { WG responsibility }\end{array}$ & - & - & - & - & - \\
\hline
\end{tabular}

Note. Cat $=$ Category, $\mathrm{PPP}=$ Public-private Participation, $\mathrm{IE}=$ Ineffectiveness, IA $=$ Inadequacy, $\mathrm{P}=$ Positive Attitude, PM= Performance Measure, AMF= Acquisition Management Framework, AOP = Acquisition Operational Process, LCC = Life Cycle Cost, Q = Question, G/Gov = Good Governance.

Table 7. Summarized the survey results for the Worker Group

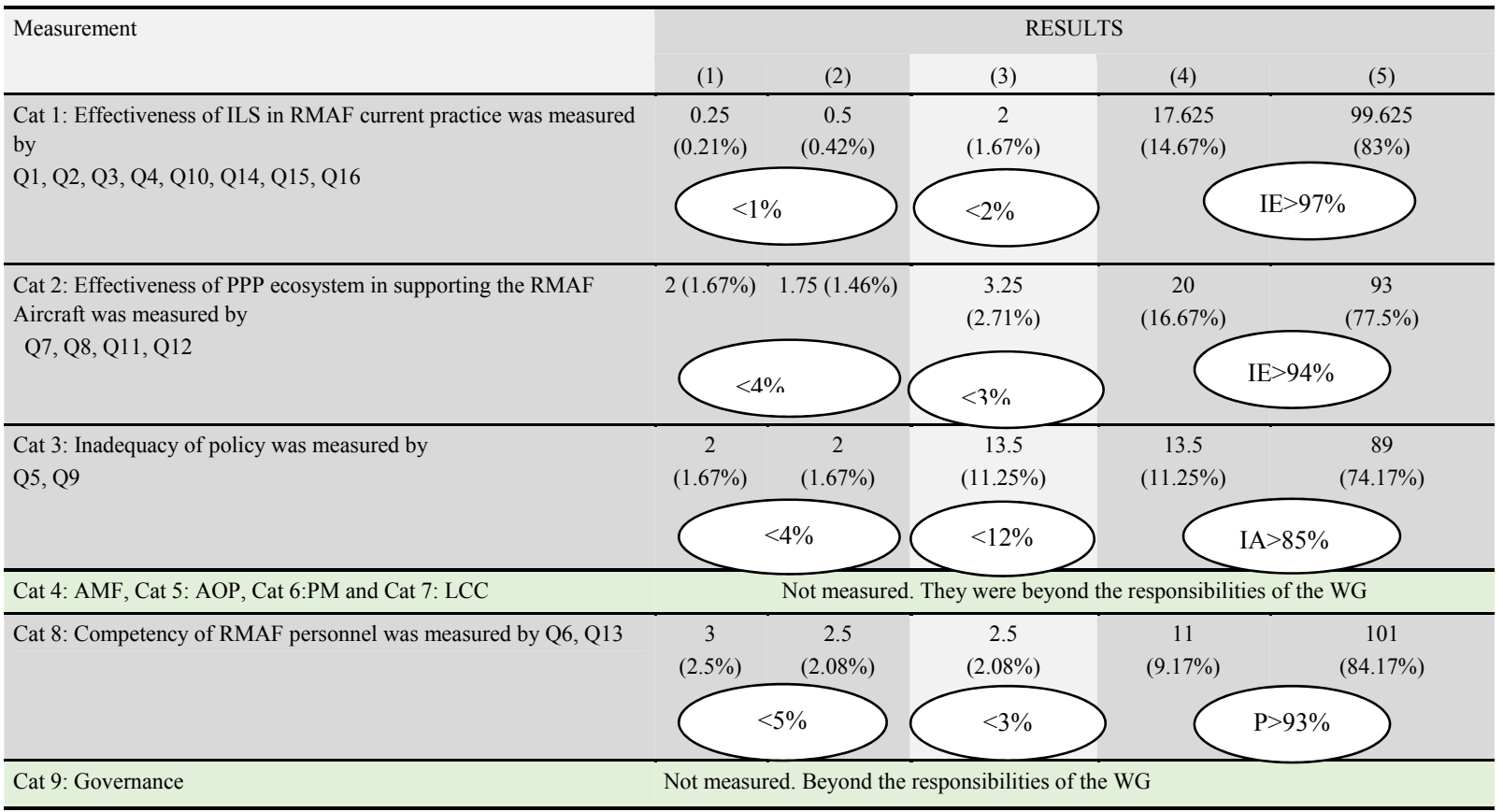

Note. Cat $=$ Category, PPP $=$ Public-private Participation, IE $=$ Ineffectiveness, $\mathrm{IA}=$ Inadequacy, $\mathrm{P}=$ Positive Attitude, $\mathrm{PM}=$ Performance Measure, $\mathrm{AMF}=$ Acquisition Management Framework, AOP $=$ Acquisition Operational Process, $\mathrm{LCC}=$ Life Cycle Cost, $\mathrm{Q}=$ Question.

Table 7 showed the survey results for category one: the effectiveness of ILS in RMAF present practice was measured. Approximately 117 out of 120 respondents ( $>97 \%)$ selected the answer either, "strongly agree" or "agree", "always", and "most of the time" which indicated the ineffectiveness of ILS in RMAF present practice (IE $>97 \%$ ). Less than $2 \%$ of respondent, was neutral and only $1 \%$ disagreed and strongly disagreed. For category two measured the effectiveness of PPP ecosystem in RMAF aerospace defence industry. The results showed that, approximately 113 out of 120 respondents (>94\%) answered either, "strongly agree", "agree", which indicated 
ineffectiveness of present PPP ecosystem in RMAF aerospace defence industry (IE $>94 \%$ ). Less than 3\% of respondent was neutral and approximately $4 \%$ disagreed and strongly disagreed. For category three, measured adequacy of regulation, policy and procedure in acquisition. The results showed approximately 102 out of 120 respondents $(>85 \%)$ answered either, "strongly agree" or "agree", which indicated inadequacy (IA $>85 \%)$ of regulation, policy and procedure in supporting the RMAF present acquisition process. Less than $12 \%$ of respondent was neutral and approximately $4 \%$ disagreed and strongly disagreed. For category 4, 5, 6, and 7 were not measured due to beyond WG responsibilities. For category eight, measured the competency of RMAF personnel involved in acquisition. The results showed approximately 112 out of 120 respondents (>93\%) answered either, "strongly agreed" or "agreed", to indicate high competency of RMAF personnel. Less than 3\% of respondent was neutral and approximately $5 \%$ disagreed and strongly disagreed with that statement. In the next section, the survey results for WG will be compared to interview results from MG.

\subsubsection{Interview Results from Management Group}

Durugbo and Erkoyuncu (2016) in a case study on mitigating uncertainty for industrial service operations had conducted a multi case study which is guided by research questions, coding process, data cleaning, close reading, categorization, overlapping coding and revision. They considered overlapping coding and encoded text, and also omission. For this project, ideas were adopted and questionnaires for the MG were divided into nine categories (based on the nine CSFs in acquisition) in order to make it measureable. Categories and sub-categories that have strong contingent effects in the acquisition and aircraft Av relationship are presented in Column (a) and defined in Column (b). Column (c) provides the questionnaires. Column (d) provides answers from the interviews. Column (e) provides the number of repetitive theme or words related to each category and sub-category. Column (f) provides information on the repetitive themes or words and the percentage from the total themes. Column (g) provides suggestions or recommendations received from respondents for further improvements. The survey results for the MG are shown in Table 8.

Table 8. Interview results for the Management Group

\begin{tabular}{|c|c|c|c|c|c|c|}
\hline $\begin{array}{l}\text { Measure } \\
\text { Categories / } \\
\text { Sub } \\
\text { Categories } \\
\text { (a) }\end{array}$ & $\begin{array}{c}\text { Categories / Sub } \\
\text { Categories } \\
\text { Definition } \\
\text { (b) }\end{array}$ & $\begin{array}{l}\text { Questionnaires } \\
\text { (c) }\end{array}$ & $\begin{array}{l}\text { Answers } \\
\text { (d) }\end{array}$ & $\begin{array}{l}\text { No. of } \\
\text { Repetitive } \\
\text { Theme } \\
\text { (e) }\end{array}$ & $\begin{array}{l}\text { Repetitive } \\
\text { Theme/ } \\
\text { Total } \\
\text { Themes } \\
\text { (f) }\end{array}$ & $\begin{array}{c}\text { Recommendations } \\
\text { (Repetitive Themes) } \\
\text { (g) }\end{array}$ \\
\hline \multirow[t]{3}{*}{$\begin{array}{l}\text { Cat 1: } \\
\text { Effectiveness } \\
\text { (E) of ILS in } \\
\text { RMAF Present } \\
\text { Practice } \\
\text { (Q1, Q3, Q5) }\end{array}$} & \multirow[t]{3}{*}{$\begin{array}{l}\text { Whether ILS is } \\
\text { effective (E)/ } \\
\text { ineffective (IE) } \\
\text { in current } \\
\text { RMAF practice }\end{array}$} & $\begin{array}{l}\text { Q1. In your opinion, what do } \\
\text { you think about the } \\
\text { effectiveness of integrated } \\
\text { logistic support in RMAF } \\
\text { acquisition? Do you want to } \\
\text { add any comment? }\end{array}$ & $\begin{array}{l}\text { - ILS is not } \\
\text { structured, } \\
\text { unorganized, ad hoc } \\
\text { basis, unclear } \\
\text { process and process } \\
\text { owner. }\end{array}$ & $\begin{array}{l}\text { (IE) } 19 \\
\text { (E) } 1 \\
\text { (O) } 3\end{array}$ & & \multirow{3}{*}{$\begin{array}{l}\text { - Reorganize the ILS } \\
\text { framework - Agreed with } \\
\text { proposal to include ILS } \\
\text { ten principle elements and } \\
\text { ILS ten supporting } \\
\text { elements. } \\
\text { - Develop ILS process by } \\
\text { project Team (ILS } \\
\text { Manager) at MPOU and } \\
\text { Material Department } \\
\text { MINDEF } \\
\text { - ILS started in early } \\
\text { acquisition phase and to } \\
\text { be ready at least } 2 \text { years } \\
\text { before aircraft entering } \\
\text { into service (EIS). } \\
\text {-Competency of personnel } \\
\text { and project team. } \\
\text { - Early warning for } \\
\text { aircraft disposal or at least } \\
2 \text { years before disposal. } \\
\text {-Explicit checklist and } \\
\text { process in acquisition. } \\
\text {-Measuring ILS through } \\
\text { PBL. } \\
\text {-All ILS documentations } \\
\text { i.e. LSAR were to be kept } \\
\text { at MINDEF - MPOU } \\
\text { Office. } \\
\text { (IE)56, E(4), (O)9. }\end{array}$} \\
\hline & & $\begin{array}{l}\text { Q3. To what extent you are } \\
\text { satisfied with the effectiveness } \\
\text { of ILS in acquisition process? } \\
\text { Do you want to add any } \\
\text { comment? }\end{array}$ & $\begin{array}{l}\text {-Unavailability of } \\
\text { specific ILS } \\
\text { process in overall } \\
\text { acquisition } \\
\text { process. }\end{array}$ & $\begin{array}{l}\text { (IE)18 } \\
\text { (E) } 2 \\
\text { (O) } 5\end{array}$ & (IE)56/69 & \\
\hline & & $\begin{array}{l}\text { Q5. Are you satisfied with } \\
\text { proposal for integrated } \\
\text { logistics support Framework in } \\
\text { RMAF? By referring to ILS do } \\
\text { you want to add any comment } \\
\text { on that framework? }\end{array}$ & $\begin{array}{l}\text {-Ineffective ILS. } \\
\text {-Agree with the } \\
\text { proposal. Not in ad } \\
\text { hoc basis; shall } \\
\text { have timeframe. }\end{array}$ & $\begin{array}{l}\text { (IE) } 19 \\
\text { (E) } 1 \\
\text { (O) } 1\end{array}$ & $(81.16 \%)$ & \\
\hline
\end{tabular}




\begin{tabular}{|c|c|c|c|c|c|c|}
\hline $\begin{array}{l}\text { Measure } \\
\text { Categories / } \\
\text { Sub } \\
\text { Categories } \\
\text { (a) }\end{array}$ & $\begin{array}{l}\text { Categories / Sub } \\
\text { Categories } \\
\text { Definition } \\
\text { (b) }\end{array}$ & $\begin{array}{l}\text { Questionnaires } \\
\text { (c) }\end{array}$ & $\begin{array}{l}\text { Answers } \\
\text { (d) }\end{array}$ & $\begin{array}{l}\text { No. of } \\
\text { Repetitive } \\
\text { Theme } \\
\text { (e) }\end{array}$ & $\begin{array}{l}\text { Repetitive } \\
\text { Theme/ } \\
\text { Total } \\
\text { Themes } \\
\text { (f) }\end{array}$ & $\begin{array}{c}\text { Recommendations } \\
\text { (Repetitive Themes) } \\
\text { (g) }\end{array}$ \\
\hline \multirow{4}{*}{$\begin{array}{l}\text { Cat 2: } \\
\text { Effectiveness } \\
\text { of PPP } \\
\text { ecosystem for } \\
\text { RMAF and } \\
\text { aerospace } \\
\text { defence industry } \\
\text { was measured } \\
\text { by Q8, Q11, } \\
\text { Q14 }\end{array}$} & \multirow{4}{*}{$\begin{array}{l}\text { Whether the } \\
\text { ecosystem for } \\
\text { PPP is effective } \\
\text { (E)/ ineffective } \\
\text { (IE) in current } \\
\text { RMAF practice } \\
\text { y }\end{array}$} & $\begin{array}{l}\text { Q8. To what extent you are } \\
\text { satisfied with spare parts } \\
\text { manufacturing by local } \\
\text { industries in order to support } \\
\text { RMAF aircraft operation. Do } \\
\text { you want to elaborate further? }\end{array}$ & $\begin{array}{l}\text { Our industries are } \\
\text { nowhere. Industry } \\
\text { need to produce } \\
\text { aircraft spares } \\
\text { locally. }\end{array}$ & $\begin{array}{l}\text { (IE) } 21 \\
\text { (E) } 2 \\
\text { (O) } 1\end{array}$ & \multirow[b]{2}{*}{$\begin{array}{l}(\mathrm{IE}) 62 / 71 \\
(87.32 \%) \\
(\mathrm{E}) 6 / 71 \\
(8.45 \%) \\
(\mathrm{O}) 3 / 71 \\
(4.23 \%)\end{array}$} & \multirow{2}{*}{$\begin{array}{l}\text {-The DID and MIGHT } \\
\text { has to propose PPP } \\
\text { ecosystem to MINDEF } \\
\text { for approval. } \\
\text {-PPP process flow: } \\
\text { MPOU Office in } \\
\text { collaboration with } \\
\text { Engineering Department } \\
\text { (Secretariat) to advice } \\
\text { members of KK Aero. }\end{array}$} \\
\hline & & $\begin{array}{l}\text { Q11.To what extent you agreed } \\
\text { with the proposal of Ecosystem } \\
\text { for PPP in acquisition. Do you } \\
\text { want to add any comment on } \\
\text { the ecosystem framework? } \\
\text { Any additional comment? }\end{array}$ & $\begin{array}{l}\text {-Agree. The } \\
\text { RMAF and } \\
\text { industries need to } \\
\text { work } \\
\text { hand-in-hand. } \\
\text {-win-win situation } \\
\text { concept. } \\
\text {-Healthy } \\
\text { ecosystem. } \\
\text {-Fair chances for } \\
\text { industries to } \\
\text { participate. }\end{array}$ & $\begin{array}{l}\text { (IE) } 19 \\
\text { (E) } 2 \\
(\mathrm{O})-\end{array}$ & & \\
\hline & & $\begin{array}{l}\text { Q14. In your opinion, do you } \\
\text { satisfy with public private } \\
\text { participation in supporting } \\
\text { RMAF aircraft operation? If } \\
\text { not, what need to be done? Do } \\
\text { you want to add any comment? }\end{array}$ & $\begin{array}{l}\text {-Unorganized } \\
\text { ecosystem, ad-hoc, } \\
\text {-Unavailability of } \\
\text { specific PPP flow } \\
\text { process in AOP } \\
\text { and process owner. } \\
\text {-Limited } \\
\text { participation } \\
\text { (Focus on five } \\
\text { pillars industries). }\end{array}$ & $\begin{array}{l}\text { (IE)22 } \\
(\mathrm{E}) 2 \\
(\mathrm{O}) 2\end{array}$ & & $\begin{array}{l}\text {-Industries and RMAF to } \\
\text { involved in offset } \\
\text { program. }\end{array}$ \\
\hline & & TOTAL THEMES & & 71 & & \\
\hline \multirow[t]{4}{*}{$\begin{array}{l}\text { Cat 3: } \\
\text { Adequacy of } \\
\text { regulation, } \\
\text { policy, } \\
\text { procedures } \\
\text { related to } \\
\text { acquisition in } \\
\text { RMAF present } \\
\text { practice } \\
(\mathrm{Q} 2, \mathrm{Q} 4, \mathrm{Q} 9, \\
\text { Q10, Q15) }\end{array}$} & \multirow[t]{4}{*}{$\begin{array}{l}\text { Whether } \\
\text { regulation, } \\
\text { policies related } \\
\text { to acquisition } \\
\text { are adequate } \\
\text { (A)/ inadequate } \\
\text { (IA) in RMAF } \\
\text { present practice. }\end{array}$} & $\begin{array}{l}\text { Q2. To what extend you are } \\
\text { satisfied with the policy in } \\
\text { Integrated Logistics Support to } \\
\text { support aircraft operation. If you } \\
\text { are not satisfied, why? Do you want } \\
\text { to add any comment? } \\
\text { Q4. In your opinion, do you think } \\
\text { that regulations at national level are } \\
\text { adequate to support the RMAF } \\
\text { aircraft acquisition? Do you want to } \\
\text { add any comment? }\end{array}$ & $\begin{array}{l}\text { Inadequate. Need } \\
\text { development and } \\
\text { revision. ILS not } \\
\text { clearly discussed on } \\
\text { support elements and } \\
\text { process owner. } \\
\text { Inadequate especially } \\
\text { on spares } \\
\text { manufacturing by } \\
\text { local industry. }\end{array}$ & $\begin{array}{l}\text { (IA) } 19 \\
\text { (A) } 2 \\
(\mathrm{O}) 1\end{array}$ & \multirow{4}{*}{$\begin{array}{l}(\mathrm{IA}) \\
112 / 123 \\
(91.06 \%)\end{array}$} & $\begin{array}{l}\text { - Develop/revise } \\
\text { regulations and policy } \\
\text { related to acquisition: } \\
\text { - Spares manufacturing } \\
\text { by local industry at } \\
\text { national and RMAF } \\
\text { Level. } \\
\text {-Obsolescence } \\
\text { management. } \\
\text {-Pre-delivery and final } \\
\text { acceptance test - made }\end{array}$ \\
\hline & & $\begin{array}{l}\text { Q9. To what extent you are satisfied } \\
\text { with the policy in aircraft mid-life } \\
\text { review in order to support aircraft } \\
\text { operation. Do you want to elaborate } \\
\text { further? }\end{array}$ & $\begin{array}{l}\text {-Inadequacy of policy } \\
\text { in Aircraft Mid-Live } \\
\text { Review. }\end{array}$ & $\begin{array}{l}\text { (IA) } 32 \\
\text { (A) } 2 \\
(\mathrm{O})-\end{array}$ & & $\begin{array}{l}\text { available before aircraft } \\
\text { entering into service. } \\
\text {-Aircraft mid - life } \\
\text { review } \\
\text {-Smart partnership }\end{array}$ \\
\hline & & $\begin{array}{l}\text { Q10. In your opinion, do you think } \\
\text { supporting policy for aircraft } \\
\text { acquisition is adequate? If not, what } \\
\text { policies do you think need to be } \\
\text { issued? When is the suitable time to } \\
\text { issue these policies? Do you want to } \\
\text { add any comment? }\end{array}$ & $\begin{array}{l}\text { Inadequate. Require } \\
\text { clear regulations and } \\
\text { policies. }\end{array}$ & $\begin{array}{l}\text { (IA) } 18 \\
\text { (A) } 2 \\
\text { (O)- }\end{array}$ & & $\begin{array}{l}\text { RMAF \& industry, } \\
\text {-AMF } \\
\text { included in a binding } \\
\text { contract. } \\
\text { - ILS, }\end{array}$ \\
\hline & & $\begin{array}{l}\text { Q15. To what extent you are } \\
\text { satisfied with the present RMAF } \\
\text { policy in aircraft acquisition? If not, } \\
\text { which policy needs to be issued? Do } \\
\text { you want to elaborate further? }\end{array}$ & $\begin{array}{l}\text { All related regulation, } \\
\text { policy, procedure } \\
\text { shall be made } \\
\text { available. Inadequate. }\end{array}$ & $\begin{array}{l}\text { (IA) } 22 \\
(\mathrm{~A}) 2 \\
(\mathrm{O})-\end{array}$ & & $\begin{array}{l}\text {-All regulation and } \\
\text { policies must be issued } \\
\text { at early acquisition } \\
\text { stage. }\end{array}$ \\
\hline
\end{tabular}

(IA)112, (A)10, A(1) 


\begin{tabular}{|c|c|c|c|c|c|c|}
\hline $\begin{array}{l}\text { Measure } \\
\text { Categories / } \\
\text { Sub } \\
\text { Categories } \\
\text { (a) }\end{array}$ & $\begin{array}{l}\text { Categories / Sub } \\
\text { Categories } \\
\text { Definition } \\
\text { (b) }\end{array}$ & $\begin{array}{l}\text { Questionnaires } \\
\text { (c) }\end{array}$ & $\begin{array}{l}\text { Answers } \\
\text { (d) }\end{array}$ & $\begin{array}{l}\text { No. of } \\
\text { Repetitive } \\
\text { Theme } \\
\text { (e) }\end{array}$ & $\begin{array}{l}\text { Repetitive } \\
\text { Theme/ } \\
\text { Total } \\
\text { Themes } \\
\text { (f) }\end{array}$ & $\begin{array}{c}\text { Recommendations } \\
\text { (Repetitive Themes) } \\
\text { (g) }\end{array}$ \\
\hline \multirow[t]{2}{*}{$\begin{array}{l}\text { Cat } 4 \text { : } \\
\text { Effective } \\
\text { /Ineffective of } \\
\text { AMF in } \\
\text { RMAF present } \\
\text { practice (Q16) }\end{array}$} & \multirow[t]{2}{*}{$\begin{array}{l}\text { Whether AMF } \\
\text { is effective E)/ } \\
\text { Ineffective (IE) } \\
\text { in RMAF } \\
\text { present practice. }\end{array}$} & $\begin{array}{l}\text { Q16. To what extent you are } \\
\text { satisfied with present RMAF's } \\
\text { acquisition management } \\
\text { framework. By referring to } \\
\text { the AMF handed over to you } \\
\text { earlier, do you want to add any } \\
\text { comment on that framework? }\end{array}$ & $\begin{array}{l}\text {-Unavailability of } \\
\text { AMF tailored to } \\
\text { the RMAF } \\
\text { requirements. } \\
\text {-Guideline issued } \\
\text { by MoF is too } \\
\text { generic. } \\
\text { - Lead to } \\
\text { weaknesses in } \\
\text { TLCS, higher } \\
\text { aircraft downtime } \\
\text { and low Av. }\end{array}$ & $\begin{array}{l}\text { (IE)23 } \\
\text { (E)1 } \\
(\mathrm{O}) 2\end{array}$ & $\begin{array}{l}\text { (IE) } 23 / 26 \\
(88.46 \%)\end{array}$ & \multirow[t]{2}{*}{$\begin{array}{l}\text {-AMF from MoF } \\
\text { tailored } \\
\text { to the RMAF's } \\
\text { specific } \\
\text { requirement. } \\
\text { AMF consist of } \\
\text { CSF in acquisition } \\
\text { - Required checklist } \\
\text { with time frame for } \\
\text { every action. } \\
\text { Owner is } \\
\text { MPOU-Project } \\
\text { Team. } \\
\text { - require mid-life review } \\
\text { (IE)23, (E)1, O(2) }\end{array}$} \\
\hline & & TOTAL THEMES & & 26 & & \\
\hline \multirow[t]{2}{*}{$\begin{array}{l}\text { Cat5: } \\
\text { Effective/ } \\
\text { Ineffective of } \\
\text { AOP in } \\
\text { RMAF } \\
\text { Current } \\
\text { Practice (Q18) }\end{array}$} & \multirow[t]{2}{*}{$\begin{array}{l}\text { Whether AOP is } \\
\text { effective (E)/ } \\
\text { ineffective (IE) } \\
\text { in RMAF } \\
\text { present practice }\end{array}$} & $\begin{array}{l}\text { Q18. To what extent you are } \\
\text { satisfied with the present } \\
\text { RMAF's acquisition } \\
\text { operational process. By } \\
\text { referring to the acquisition } \\
\text { operational process handed } \\
\text { over to you earlier, do you } \\
\text { want to add any comment on } \\
\text { that process? }\end{array}$ & $\begin{array}{l}\text {-Unorganized CSF } \\
\text { in RMAF AOP, } \\
\text { unclear process } \\
\text { owner and } \\
\text { separately } \\
\text { discussed. } \\
\text {-Unavailability of } \\
\text { explicit process } \\
\text { and process owner } \\
\text { related to ILS and } \\
\text { PPP in AOP. }\end{array}$ & $\begin{array}{l}\text { (IE)23 } \\
\text { (E)2 } \\
(\mathrm{O})-\end{array}$ & \multirow[t]{2}{*}{$\begin{array}{l}\text { (IE) } 23 / 25 \\
(92 \%) \\
\text { (E) } 2 / 25 \\
(8 \%) \\
(\mathrm{O})-\end{array}$} & \multirow[t]{2}{*}{$\begin{array}{l}\text { Avoid ad-hoc } \\
\text { Implementation: } \\
\text { - AOP in line with } \\
\text { NDP. } \\
\text {-Integrated of CSFs } \\
\text { in acquisition. } \\
\text {-explicit in-house } \\
\text { AOP. } \\
\text { Explicit acquisition } \\
\text { process \& process owner } \\
\text { - To include ILS } \\
\text { and PPP process } \\
\text { flow in AOP. } \\
\text { (IE)23, (E)2, (O) - }\end{array}$} \\
\hline & & TOTAL THEMES & & 25 & & \\
\hline \multirow{3}{*}{$\begin{array}{l}\text { Cat 6: } \\
\text { Adequacy/ } \\
\text { inadequacy of } \\
\text { performance } \\
\text { measure in } \\
\text { RMAF } \\
\text { practice was } \\
\text { measured by } \\
\text { Q17, Q19. }\end{array}$} & \multirow[t]{3}{*}{$\begin{array}{l}\text { Whether PM is } \\
\text { inadequate (IA)/ } \\
\text { Adequate (A) in } \\
\text { current RMAF } \\
\text { practice }\end{array}$} & $\begin{array}{l}\text { Q17. In your opinion, do you } \\
\text { think the performance measure in } \\
\text { acquisition focused on aircraft } \\
\text { availability is adequate? Do you } \\
\text { want to elaborate further? }\end{array}$ & $\begin{array}{l}\text {-Inadequate. } \\
\text {-Do not rely only } \\
\text { on availability. }\end{array}$ & $\begin{array}{l}\text { (IA)19 } \\
\text { (A)1 } \\
(\mathrm{O}) 1\end{array}$ & \multirow{2}{*}{$\begin{array}{l}\text { (IA) } 39 / 43 \\
(90.7 \%) \\
\text { (A) } 2 / 43 \\
(4.65 \%) \\
(\mathrm{O}) 2 / 43 \\
(4.65 \%)\end{array}$} & \multirow{2}{*}{$\begin{array}{l}\text {--Performance } \\
\text { measurement shall } \\
\text { have considered the } \\
\text { whole acquisition } \\
\text { process to disposal } \\
\text { phase. } \\
\text {-Agreement shall be } \\
\text { registered as binding } \\
\text { contract } \\
\text { (IA)39, (A)2, (O)2 }\end{array}$} \\
\hline & & $\begin{array}{l}\text { Q19. To what extent you agree } \\
\text { that, the measurement of aircraft } \\
\text { availability will monitor the } \\
\text { whole acquisition process? Do } \\
\text { you want to add any comment? }\end{array}$ & $\begin{array}{l}\text { Need to find a } \\
\text { better performance } \\
\text { measure. }\end{array}$ & $\begin{array}{l}\text { (IA) } 20 \\
\text { (A) } 1 \\
\text { (O) } 1\end{array}$ & & \\
\hline & & TOTAL THEMES & & 43 & & \\
\hline \multirow{3}{*}{$\begin{array}{l}\text { Cat 7: } \\
\text { Effective/ } \\
\text { ineffective of } \\
\text { LCC was } \\
\text { measured by } \\
\text { Q6, Q7. }\end{array}$} & \multirow{3}{*}{$\begin{array}{l}\text { Whether the } \\
\text { LCC is effective } \\
\text { (E)/ ineffective } \\
\text { (IE) }\end{array}$} & $\begin{array}{l}\text { Q6. In your opinion, do you think } \\
\text { life cycle cost in RMAF } \\
\text { acquisition has considered all } \\
\text { cost involved? Do you want to } \\
\text { add any comment? }\end{array}$ & $\begin{array}{l}\text { Not calculate } \\
\text { whole cost. }\end{array}$ & $\begin{array}{l}\text { (IE)24 } \\
\text { (E)1 } \\
\text { (O)1 }\end{array}$ & \multirow{2}{*}{$\begin{array}{l}\text { (IE) } 47 / 51 \\
(92.16 \%) \\
\text { (E) } 2 / 51 \\
(3.92 \%) \\
(\mathrm{O}) 2 / 51 \\
(3.92 \%)\end{array}$} & \multirow{2}{*}{$\begin{array}{l}\text { LCC to consider whole } \\
\text { cost required in aircraft } \\
\text { life cycle: ownership } \\
\text { cost until the disposal } \\
\text { cost. Maintenance \& } \\
\text { operation cost, mid-life } \\
\text { review \& upgrading } \\
\text { cost, }\end{array}$} \\
\hline & & $\begin{array}{l}\text { Q7. What do you think about the } \\
\text { adequacy of life cycle cost } \\
\text { implementation in RMAF } \\
\text { acquisition practice? Do you } \\
\text { want to add any comment? }\end{array}$ & Inadequate & $\begin{array}{l}\text { (IE)23 } \\
\text { (E)1 } \\
\text { (O) } 1\end{array}$ & & \\
\hline & & TOTAL THEMES & & 51 & & (IE)47, (E)2, (O)2 \\
\hline \multirow{3}{*}{$\begin{array}{l}\text { Cat 8: } \\
\text { Competency } \\
\text { of RMAF } \\
\text { Personnel } \\
\text { Q12 and Q13. }\end{array}$} & \multirow{2}{*}{$\begin{array}{l}\text { Whether } \\
\text { Competent (C) / } \\
\text { Required } \\
\text { Improvement } \\
\text { (RI) among } \\
\text { personnel who } \\
\text { involved in } \\
\text { acquisition } \\
\text { process. }\end{array}$} & $\begin{array}{l}\text { Q12. What do you think about } \\
\text { the competency of RMAF } \\
\text { personnel involved in the } \\
\text { acquisition process? Do you want } \\
\text { to add any comment? }\end{array}$ & $\begin{array}{l}\text { RMAF Level - Ok. } \\
\text { They are } \\
\text { committed. }\end{array}$ & $\begin{array}{l}(\mathrm{P}) 25 \\
(\mathrm{~N}) 1 \\
(\mathrm{O})-\end{array}$ & \multirow{2}{*}{$\begin{array}{l}\text { (P) } 50 / 52 \\
(96.15 \%) \\
\text { (N) } 2 / 52 \\
(3.85 \%)\end{array}$} & $\begin{array}{l}\frac{\text { Support from }}{\text { competence \& high tech. }} \\
\frac{\text { MRO }}{\text { - Concept phase industry }} \\
\text { involvement. }\end{array}$ \\
\hline & & $\begin{array}{l}\text { Q13. In your opinion, what do } \\
\text { you think about the competency } \\
\text { of every department in RMAF } \\
\text { acquisition process? Do you want } \\
\text { to add any comment? }\end{array}$ & $\begin{array}{l}\text { At RMAF Level - } \\
\text { OK. Government } \\
\text { programs to } \\
\text { enhance good } \\
\text { governance and } \\
\text { attitude. }\end{array}$ & $\begin{array}{l}(\mathrm{P}) 25 \\
(\mathrm{~N}) 1 \\
(\mathrm{O})-\end{array}$ & & $\begin{array}{l}\text { - MRO competency. } \\
\text { - competency to } \\
\text { RMAF personnel. } \\
\text {-Work together with } \\
\text { industry in offset } \\
\text { program } \\
(\mathbf{G ) ~} 50,(\mathbf{R I}) 2,(\mathbf{O})\end{array}$ \\
\hline & & TOTAL THEMES & & 52 & & \\
\hline
\end{tabular}




\begin{tabular}{|c|c|c|c|c|c|c|}
\hline $\begin{array}{l}\text { Measure } \\
\text { Categories / } \\
\text { Sub } \\
\text { Categories } \\
\text { (a) }\end{array}$ & $\begin{array}{c}\text { Categories / Sub } \\
\text { Categories } \\
\text { Definition } \\
\text { (b) }\end{array}$ & $\begin{array}{l}\text { Questionnaires } \\
\text { (c) }\end{array}$ & $\begin{array}{l}\text { Answers } \\
\text { (d) }\end{array}$ & $\begin{array}{l}\text { No. of } \\
\text { Repetitive } \\
\text { Theme } \\
\text { (e) }\end{array}$ & $\begin{array}{l}\text { Repetitive } \\
\text { Theme/ } \\
\text { Total } \\
\text { Themes } \\
\text { (f) }\end{array}$ & $\begin{array}{c}\text { Recommendations } \\
\text { (Repetitive Themes) } \\
\text { (g) }\end{array}$ \\
\hline \multirow[t]{4}{*}{$\begin{array}{l}\text { Cat 9: } \\
\text { Governance in } \\
\text { Acquisition } \\
\text { was measured } \\
\text { by } \\
\text { Q20 and Q21 }\end{array}$} & \multirow[t]{2}{*}{$\begin{array}{l}\text { Whether good } \\
\text { (G) / Require } \\
\text { Improvement } \\
\text { (RI) in } \\
\text { governance for } \\
\text { RMAF aircraft } \\
\text { acquisition }\end{array}$} & $\begin{array}{l}\text { Q20. To what extent you agree } \\
\text { that, all departments outside } \\
\text { RMAF has practice good } \\
\text { governance in RMAF aircraft } \\
\text { acquisition process? Do you } \\
\text { want to add any comment? }\end{array}$ & $\begin{array}{l}\text {-Need further } \\
\text { study to confirm } \\
\text { actual situation, } \\
\text { need enforcement, } \\
\text { in doubt. and no } \\
\text { comment. }\end{array}$ & $\begin{array}{l}(\mathrm{N}) 12 \\
(\mathrm{O}) 11\end{array}$ & \multirow[t]{2}{*}{$\begin{array}{l}(\mathrm{P}) 21 / 60 \\
(35 \%) \\
(\mathrm{N}) 22 / 60 \\
(36.67 \%)\end{array}$} & \multirow{2}{*}{$\begin{array}{l}\text { - The implementation } \\
\text { of 'work ethics', good } \\
\text { governance practice } \\
\text { and etc. } \\
\text { (P)21, (N)22, (O) } 17\end{array}$} \\
\hline & & $\begin{array}{l}\text { Q21. To what extent you are } \\
\text { satisfied with the governance } \\
\text { of aircraft acquisition process } \\
\text { which beyond the RMAF } \\
\text { control? Do you want to add } \\
\text { any comment? }\end{array}$ & $\begin{array}{l}\text {-It is the } \\
\text { government } \\
\text { decision to buy or } \\
\text { not to buy'. -In } \\
\text { doubt. }\end{array}$ & $\begin{array}{l}(\mathrm{P}) 10 \\
(\mathrm{~N}) 10 \\
(\mathrm{O}) 6\end{array}$ & & \\
\hline & & TOTAL THEME & & 60 & & \\
\hline & \multicolumn{2}{|c|}{ GRAND TOTAL THEME } & & 520 & & \\
\hline
\end{tabular}

From Table 8, this project has adopted:

One Complete Theme $=$ A combination of answer $(\mathrm{d})$ and recommendation by the respondent $(\mathrm{g})$

*Answers (d) without recommendation $(\mathrm{g})$ require further clarification from respondents.

There were 520 total themes, with 69 themes related to Cat 1: Effectiveness of ILS in RMAF Present Practice, 71 themes related to the effectiveness of the PPP ecosystem in the RMAF and the aerospace defence industry, 123 themes related to regulations and policy in RMAF's acquisition practices, 123 themes focusing on Cat 3: the effectiveness of AMF in the RMAF's current practices, 26 themes related to Cat 4: Effectiveness (E) of AMF in the RMAF's current practices, 25 themes focused on Cat 5: the effectiveness of AOP in RMAF's current practices, 43 themes related to Cat 6: Adequacy of performance measures, 51 themes focused on Cat 7: Effectiveness of LCC implementation in the RMAF, 52 themes related to Cat 8: competency of the RMAF personnel involved in the acquisition process, and 60 themes related to Cat 9: Measurement of governance in the RMAF's acquisition process.

Category One: 56 out of 69 themes (81.16\%) showed the ineffectiveness (IE) of ILS in the RMAF's practices, while only $4 / 69$ (5.797\%) repetitive themes showed the effectiveness (E) of the ILS in the RMAF's practices and 9/69 (13.04\%) themes were omitted as they are not related to the research. The respondents highlighted 56 repetitive themes as suggestions for further improvement of the ILS.

Category Two: 62 out of 71 themes (87.32\%) indicated the ineffectiveness (IE) the of PPP ecosystem for the RMAF and the aerospace defence industry. Only 6/71 (8.45\%) repetitive themes showed that PPP is effective (E) and $3 / 71$ themes were omitted as they are not related to the research or have unclear clarification. The respondents highlighted 62 repetitive themes as suggestions to improve the PPP ecosystem for the RMAF and the aerospace defence industry.

Category Three: 112 out of 123 themes (91.06\%) indicated the inadequacy (IA) of regulations, policy, and procedures related to the RMAF's current acquisition practices. Only 10/123 (8.13\%) repetitive themes showed adequacy (A) and 1/123 theme was omitted as it is not related to the research and has unclear clarification. The respondents highlighted 112 themes (with some of the themes repetitively highlighted) as suggestions to improve regulation and policy, especially on aircraft spares manufacturing by the local industry.

Category Four: 23 out of 26 themes (88.46\%) indicated ineffectiveness (IE) of the AMF due to the ad hoc basis of its implementation. Only 1/26 (3.85\%) theme is effective (E) (ad hoc AMF) and 2/26 themes were omitted as they are not related to the research or have unclear clarification. The respondents highlighted 23 themes (with some of the themes repetitively highlighted) as recommendations to improve the AMF.

Category Five: 23 out of 25 themes (92\%) indicated ineffectiveness (IE) of the AOP due to the unavailability of the ILS and PPP processes in the AOP. Only $2 / 25(8 \%)$ themes showed effectiveness (E) of the present AOP, and no themes were omitted. The respondents highlighted 23 themes (with some of the themes repetitively 
highlighted) for improvements which are focused on the development of the ILS and PPP processes in the RMAF's AOP.

Category Six: 23 out of 26 themes (88.46\%) indicated ineffectiveness (IE) of the AMF due to the unavailability of AMF. Only 1/26 (3.85\%) theme showed the effectiveness (E) of ad hoc AMF and 2/26 themes were omitted as they are not related to the research or have unclear clarification. The respondents highlighted 23 themes (with some of the themes repetitively highlighted) as recommendations to improve the AMF.

Category Seven: 47 out of 51 themes (92.16\%) indicated ineffectiveness (IE) of the LCC implementation. Only $2 / 51(3.92 \%)$ themes showed the effectiveness (E) of its implementation and $2 / 51(3.92 \%)$ themes were omitted as they are not related to the research. The respondents highlighted 47 themes (with some of the themes repetitively highlighted) as recommendations for further improvement.

Category Eight: 50 out of 52 themes (96.15\%) indicated good competency of the RMAF personnel who are involved in the acquisition process. Only $2 / 52(3.85 \%)$ themes requested improvements in terms of competency, and no themes were omitted. The respondents highlighted 50 themes (with some of the themes repetitively highlighted) as recommendations for further improvement.

Category Nine: 21 out of 60 themes (35\%) indicated good governance in the RMAF's acquisition process. 22/60 $(36.67 \%)$ themes needed improvement on governance, especially in areas outside the RMAF's jurisdiction while 17 themes were omitted as they are not related to the research study or have unclear clarification. The respondents highlighted 21 themes (with some of the themes repetitively highlighted) as recommendations for further improvement. The relation between the questionaires and survey results for the MG and the WG is shown in Table 9.

Table 9. The questionnaires and survey results between $\mathrm{MG}$ and $\mathrm{WG}$ and their relation

\begin{tabular}{|c|c|c|c|c|c|}
\hline $\begin{array}{l}\text { Categories / Sub categories } \\
\text { (a) }\end{array}$ & $\begin{array}{l}\text { Categories / Sub categories definition } \\
\text { (b) }\end{array}$ & $\begin{array}{l}\text { Question for WG } \\
\text { related with the } \\
\text { question for } \mathrm{MG} \\
\text { (c) }\end{array}$ & $\begin{array}{l}\text { Survey results } \\
\text { (WG) } \\
\text { (d) }\end{array}$ & $\begin{array}{l}\text { Question for } \\
\text { MG related to } \\
\text { WG } \\
\text { (e) }\end{array}$ & $\begin{array}{l}\text { Interview results (MG) } \\
\text { repetitive themes/ } \\
\text { total themes } \\
\text { (f) }\end{array}$ \\
\hline $\begin{array}{l}\text { Cat } 1: \text { Effectiveness }(\mathrm{E}) \text { of } \\
\text { ILS in RMAF }\end{array}$ & $\begin{array}{l}\text { Whether ILS is effective (E)/ ineffective } \\
\text { (IE) in RMAF practice }\end{array}$ & $\begin{array}{l}\text { Q1, Q2, Q3, Q4, } \\
\text { Q10, Q14, Q15, } \\
\text { Q16 }\end{array}$ & $\begin{array}{l}\text { IE }>97 \% \text { either } \\
\text { S/A } \\
\text { or A }\end{array}$ & Q1, Q3, Q5 & $\begin{array}{l}\text { (IE) } 56 / 69(81.16 \%) \\
\text { (E) } 4 / 69(5.797 \%) \\
\text { (O) } 9 / 69(13.04 \%)\end{array}$ \\
\hline $\begin{array}{l}\text { Category 2: Effectiveness } \\
\text { of PPP ecosystem for } \\
\text { RMAF and aerospace } \\
\text { defence industry }\end{array}$ & $\begin{array}{l}\text { Whether ecosystem for PPP is effective } \\
\text { (E)/ ineffective (IE) }\end{array}$ & Q7, Q8, Q11, Q12 & $\begin{array}{l}\text { IE }>94 \% \text { either } \\
\text { S/A or A }\end{array}$ & Q8, Q11, Q14 & $\begin{array}{l}\text { (IE) } 62 / 71(87.32 \%) \\
\text { (E) } 6 / 71(8.45 \%) \\
\text { (O) } 3 / 71(4.23 \%)\end{array}$ \\
\hline $\begin{array}{l}\text { Cat } 3 \text { : Adequacy of } \\
\text { regulations, policy, related } \\
\text { to acquisition }\end{array}$ & $\begin{array}{l}\text { Whether policies related to acquisition are } \\
\text { adequate (A)/ inadequate (IA) }\end{array}$ & Q5, Q9 & $\begin{array}{l}\text { IA }>85 \% \text { either } \\
\text { S/A or A }\end{array}$ & $\begin{array}{l}\text { Q2, Q4, Q9, } \\
\text { Q10, Q15 }\end{array}$ & $\begin{array}{l}\text { (IA) } 112 / 123(91.06 \%) \\
\text { (A) } 10 / 123(8.13 \%) \\
\text { (O) } 1 / 123(0.813 \%)\end{array}$ \\
\hline $\begin{array}{l}\text { Cat 4: Effectiveness }(\mathrm{E}) \text { of } \\
\text { AMF in RMAF }\end{array}$ & $\begin{array}{l}\text { Whether AMF is effective (E)/ ineffective } \\
\text { (IE) }\end{array}$ & $\begin{array}{l}\text { Not measured. } \\
\text { Only for MG }\end{array}$ & - & (Q16) & $\begin{array}{l}\text { (IE) } 23 / 26(88.46 \%) \\
\text { (E) } 1 / 26(3.85 \%) \\
\text { (O) } 2 / 26(7.69 \%)\end{array}$ \\
\hline $\begin{array}{l}\text { Cat5: Effectiveness of } \\
\text { AOP in RMAF present } \\
\text { practice }\end{array}$ & $\begin{array}{l}\text { Whether AOP is effective (E)/ ineffective } \\
\text { (IE) }\end{array}$ & $\begin{array}{l}\text { Not measured. } \\
\text { Only for MG }\end{array}$ & - & (Q18) & $\begin{array}{l}\text { (IE) } 23 / 25(92 \%) \\
\text { (E) } 2 / 25(8 \%) \\
\text { (O)- }\end{array}$ \\
\hline $\begin{array}{l}\text { Cat 6: Adequacy of } \\
\text { performance measure }\end{array}$ & $\begin{array}{l}\text { Whether PM is inadequate (IA)/ Adequate } \\
\text { (A) }\end{array}$ & $\begin{array}{l}\text { Not measured. Only } \\
\text { for MG }\end{array}$ & - & Q17, Q19 & $\begin{array}{l}\text { (IA) } 39 / 43(90.7 \%) \\
\text { (A) } 2 / 43(4.65 \%) \\
\text { (O) } 2 / 43(4.65 \%)\end{array}$ \\
\hline $\begin{array}{l}\text { Cat 7: Effectiveness of } \\
\text { LCC implementation. }\end{array}$ & $\begin{array}{l}\text { Whether the LCC implementation is } \\
\text { effective (E)/ ineffective (IE) }\end{array}$ & $\begin{array}{l}\text { Not measured. } \\
\text { Only for MG }\end{array}$ & - & Q6, Q7 & $\begin{array}{l}\text { (IE) } 47 / 51(92.16 \%) \\
\text { (E) } 2 / 51(3.92 \%) \\
\text { (O) } 2 / 51(3.92 \%)\end{array}$ \\
\hline $\begin{array}{l}\text { Cat 8: Competency of RMAF } \\
\text { personnel }\end{array}$ & $\begin{array}{l}\text { Whether competent }(\mathrm{C}) / \text { require } \\
\text { improvement }(\mathrm{RI}) \text { among personnel } \\
\text { involved in acquisition process }\end{array}$ & Q6, Q13 & $\begin{array}{l}\mathrm{C}>93 \% \text { either } \mathrm{S} / \mathrm{A} \\
\text { or } \mathrm{A}\end{array}$ & Q12, Q13 & $\begin{array}{l}\text { (C) } 50 / 52(96.15 \%) \\
\text { (N) } 2 / 52(3.85 \%) \\
\text { (O) }-\end{array}$ \\
\hline $\begin{array}{l}\text { Cat 9: Governance } \\
\text { in acquisition }\end{array}$ & $\begin{array}{l}\text { Whether good }(\mathrm{G}) / \text { required improvement } \\
(\mathrm{RI}) \text { in governance for RMAF aircraft } \\
\text { acquisition. }\end{array}$ & $\begin{array}{l}\text { Not measured. Only } \\
\text { for MG }\end{array}$ & - & Q20, Q21 & $\begin{array}{l}\text { (G) } 21 / 60(35 \%) \\
\text { (RI) } 22 / 60(36.67 \%) \\
\text { (O) } 17(28.33 \%)\end{array}$ \\
\hline
\end{tabular}

Note. $\mathrm{S} / \mathrm{A}=$ Strongly Agreed, $\mathrm{A}=$ Agreed, $\mathrm{C}=$ High competency, $\mathrm{RI}=$ required improvement, Cat $=$ Category, $\mathrm{Q}=\mathrm{Question}, \mathrm{G}=\mathrm{Good}$ governance .

Table 9 shows the measurements for Category One: Effectiveness (E) of the ILS in the RMAF which are Q1, Q2, Q3, Q4, Q10, Q14, Q15, and Q16, and these questions are related to the MG's interview questions (Q1, Q3, Q5). The results showed that more than $97 \%(>97 \%)$ of WG respondents had either "strongly agree" or "agree", "always", and "most of the time" ad answers, indicating that the ILS in the RMAF is ineffective. The results from the WG are similar to the MG with more than $81 \%$ out of 69 total themes indicating the ILS' 
ineffectiveness in the RMAF.

Measurements for Category Two: The effectiveness of the PPP ecosystem for the RMAF and aerospace defence industry was evaluated using Q7, Q8, Q11, and Q12 for the WG and these questions are related to Q8, Q11, and Q14 of the MG's interview questions. The results showed that more than $94 \%$ of the WG respondents had either "strongly agree" or "agree" that the PPP ecosystem for the RMAF and the aerospace defence industry was ineffective. Similar results were obtained from the MG with more than $87 \%$ of the themes out of 71 total themes indicating the ineffectiveness of the PPP ecosystem.

Measurements for Category Three: The adequacy of regulations, policy, and procedures related to acquisition was evaluated using Q5 and Q9 for the WG, and these questions are related to Q2, Q4, Q9, Q10, and Q15 for the MG. The results showed that more than $94 \%$ of the WG respondents had either "strongly agree" or "agree" for the inadequacy of regulations, policy, and procedures related to acquisition. Similar results were obtained from the MG with more than $91 \%$ out of 123 total themes indicating the inadequacy of regulations, policy, and procedures to support the RMAF's acquisition process. This part had focused more on regulations and policies in the local aircraft spares manufacturing industry.

Measurement for Category Four: The effectiveness of the acquisition management framework (AMF) in current RMAF practices was evaluated using only Q16 for the MG. The results showed that more than $88 \%$ out of the 26 themes indicated the AMF's ineffectiveness.

Measurement for Category Five: The effectiveness of the AOP in the RMAF's practices was only evaluated using Q18. 92\% of out of 25 themes showed ineffectiveness of the AOP in the RMAF's practices.

Measurements for Category Six: The adequacy of performance measures used in the RMAF was evaluated using Q17 and Q19 for the MG. The results showed that more than $90 \%$ of the 43 themes indicated inadequacy of performance measures.

Measurements for Category Seven: The effectiveness of the LCC implementation in the RMAF was evaluated using Q6 and Q7 for the MG. The results showed that more than $92 \%$ out of 51 themes indicated the ineffectiveness of the LCC implementation.

Measurements for Category Eight: The competency of RMAF personnel in acquisition was evaluated using Q6 and Q13 for the WG, and these questions are related to Q12 and Q13 for the MG. The results showed that more than $93 \%$ of WG respondents had either "strongly agree" or "agree" that RMAF personnel with high competency are involved in the maintenance and acquisition process. Similar results from the MG showed that more than $96 \%$ out of 52 total themes indicated the high competency of RMAF personnel in the acquisition process.

Measurements for Category Nine: Governance in the acquisition process was evaluated using Q20 and Q21 for the MG. The results showed that $35 \%$ out of 60 themes indicated that the RMAF has practiced good governance in aircraft acquisition. However, more than 36\% suggested improvement of governance. There were consistent themes mentioned by the MG which focused on the importance of good governance and competency in acquisition.

\subsubsection{Case Study Results - Elements Associated to Acquisition}

There are 6 elements associated to acquisition from the case study results:

a. RMAF to develop and/or revise supporting regulations and policy: focus on spares manufacturing by the local industry, managing obsolescence, improving pre-delivery and final acceptance test (made available before aircraft enters into service), choosing a specific timeframe for aircraft mid - life review, smart partnerships with the industry, ILS, AOP and developing an explicit acquisition management framework. The AMF from MOF needs to be tailored to the RMAF's specific requirements and a checklist should be provided along with a timeframe for every action. The process owner is the MPOU-Project Team. It was also highlighted that all regulations and policies must be issued early in the acquisition stage and an agreement should be included as a binding contract.

b. Requirement of explicit PPP process flow \& process owner: It was highlighted that the Defence Industry Department (DID) and MIGHT has proposed a PPP ecosystem to the MoF for approval. The owner of the PPP process flow is the MPOU office in collaboration with the engineering department (secretariat) which may advice the members of the working group (KK) Aero.

c. Avoid ad-hoc implementation: Repetitive suggestions from the case study to avoid ad-hoc acquisition process. Furthermore, the acquisition operational process (AOP) has to be in line with the National Defence 
Policy. The AOP must integrate all CSFs in acquisition with explicit in-house processes to include ILS and PPP in the process flow. Reorganize the ILS framework to include the ILS' ten principles and ILS ten supporting elements, and the development of the ILS process by the project Team (ILS Manager) at MINDEF's MPOU and Material Department. ILS needs to be started early in the acquisition phase and should be ready for at least 2 years before an aircraft enters into service (EIS).

d. RMAF's preparedness for ILS, ToT and innovation in offset programs: The RMAF together with the industry should be involved in offset programs starting from the concept phase.

e. Support from competence and high technology MRO: MRO and RMAF personnel to upgrade competency and work together in offset programs.

f. Explicit acquisition process and process owner: to have explicit AOP with ILS and PPP process, along with the integration of CSFs. Good governance practices at all levels in handling the acquisition process. In addition, performance measurements are required throughout the whole acquisition process. Furthermore, all agreements must be in the form of binding contracts.

Based on the results from the survey and case study interviews, the preliminary ACF I was modified to ACF II as shown in Figure 4.

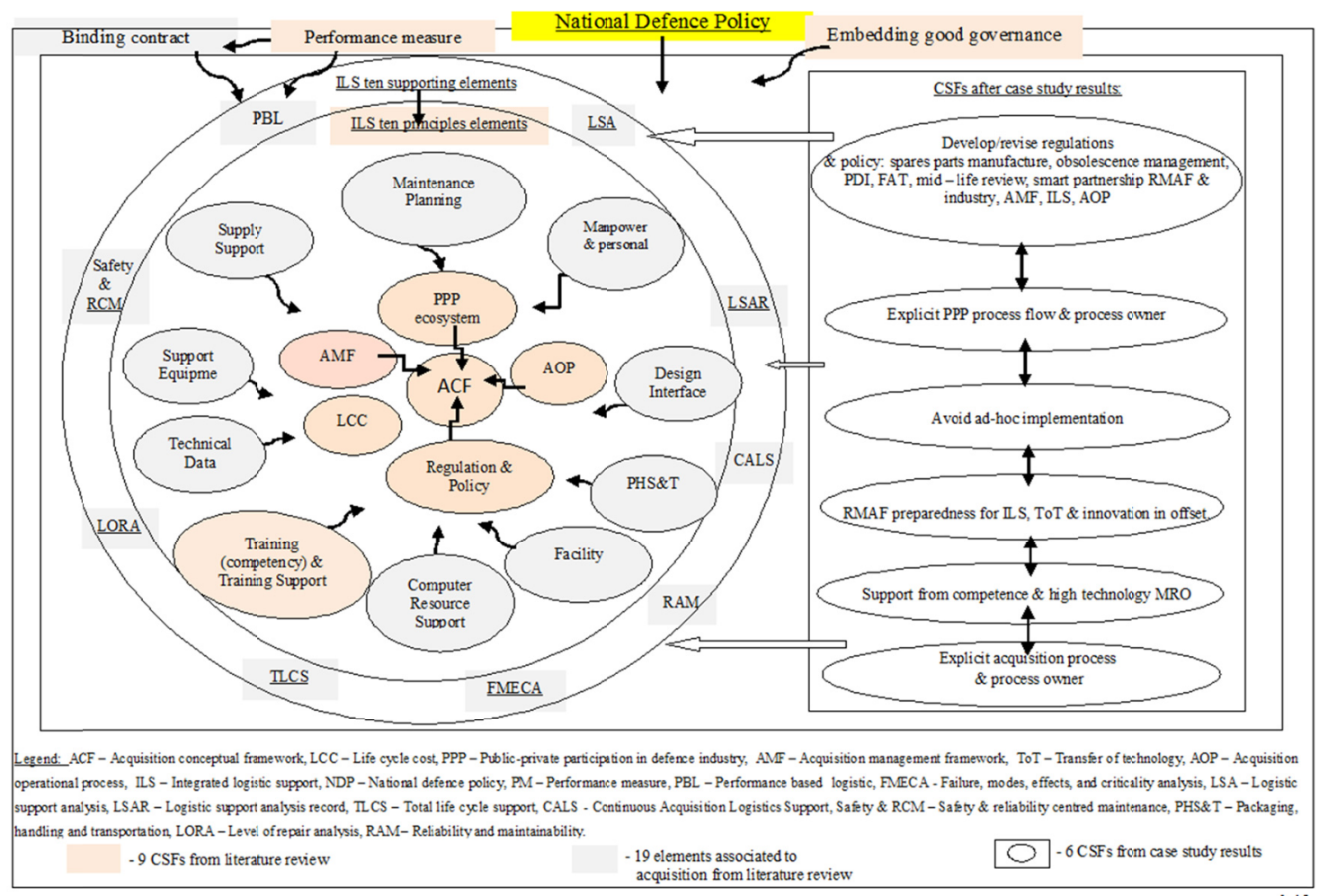

Figure 4. Acquisition conceptual framework (ACF II)

Figure 4 shows ACF II that was developed from the 9 CSFs and 19 elements associated to acquisition as suggested by the literature review conducted and the $6 \mathrm{CSFs}$ obtained from the case study results. It showed that the case study results are in line with findings from the literature review. ACF II was subjected to experts' validation to be modified to ACF III (final).

\subsection{Acquisition Conceptual Framework (ACF II) Validation Results}

ACF II was validated by four experts comprising of two senior officers and two senior managers from the aviation industry. Letters were sent to request the experts' validation and the results were recorded. The validation results were in line with findings from the literature review and the case study. The additional 5 elements associated to acquisition are as the following:

a. Require explicit regulations and policy for: spare parts manufacturing by local companies, self-reliance concept, obsolescence management, mid - life review, smart partnership with industry (e.g. RMAF's technician attached to Airod Sdn Bhd Subang for C 130 and Nuri aircraft second line servicing). 
b. Concept phase with industry involvement under the win-win situation concept. Regulations and policy should encourageindustry's early involvement in the acquisition process, but they should not directly participate in the acquisition strategy development e.g. technical representative from Sepang Aerospace Engineering (SAE) (A400M field service representative) attended A400M EASA course in Spain together with RMAF's technical personnel). However, it was expected that local companies should participate much earlier than that.

c. Fair chance for the industry to participate. Do not focus only on the five core companies e.g. Airod Sdn Bhd, Zetro Services Sdn Bhd, ATSC, Destini Prima Sdn Bhd, and Sapura Sdn Bhd.

d. Industry preparedness. Local MROs need to acquire competencies through the transfer of technology from offset programs e.g. Airod Sdn Bhd personnel were attached to No. 22 Squadron (A400M aircraft) to learn maintenance concepts. However, discussion with OEM on who is going to be the MRO is still in the pipeline. The industry requires more offset programs in order to gain knowledge and prepare for self-reliance.

e. Priority to local companies. It was highlighted that priority should be given to local companies rather than OEM to participate as MRO e.g. second line servicing for EC 725 aircraft was awarded to local company namely BHICAS. Presently, BHICAS successfully carried out a 1000 hours check for four EC 725s.

Four experts consisting of two senior officers and two industrial practitioners had validated ACF II, which was developed from the literature and case study results. ACF II was modified based on the validation results, and the final ACF III was proposed for implementation. ACF III consists of 9 CSFs and 19 elements associated with acquisition (recommended from literature review), 6 elements from case study results and 5 elements from validation results. Altogether, 39 CSFs were integrated in ACF III as shown in Figure 5.

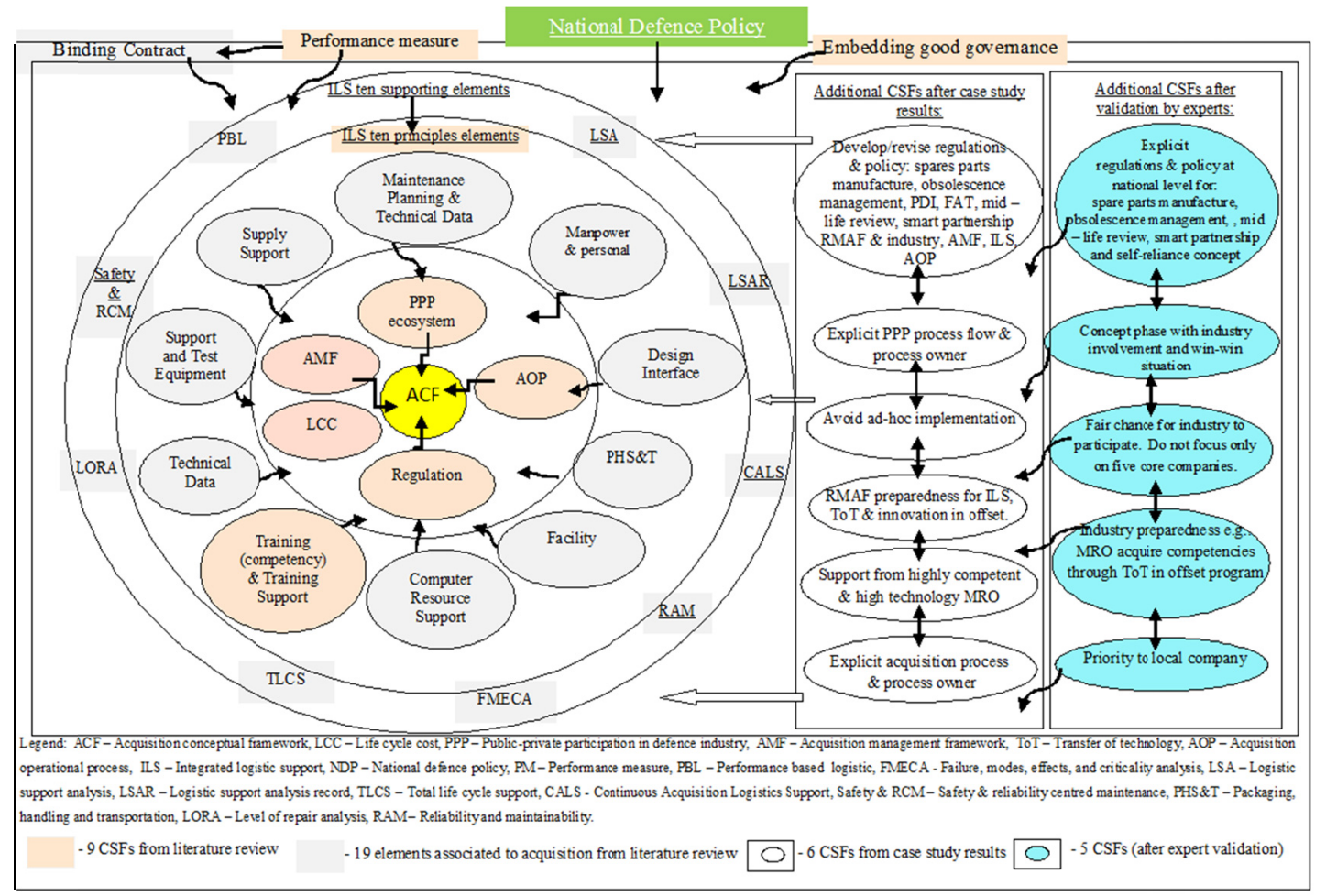

Figure 5. Acquisition conceptual framework (ACF III)

The recommended ACF III was developed from 9 CSFs in acquisition and 30 elements associated to acquisition (19 elements from literature review, 6 elements from case study results, and 5 elements from validation results).

\section{Discussion}

The aim of this section is to answer the problem statement which is "why" and "how" the aircraft in the RMAF fleet can achieve and sustain at least $70 \%$ of availability (Av). "What" is the recommended ACF that suits the RMAF's requirements and help ensure higher aircraft Av? The conclusion is based on the literature review, direct observations, comparison with literature, practices by the Malaysian public sector, sister services (Royal Malaysian Navy and Royal Malaysian Army), DoD USA, MoD UK, Australian Defence Force (ADF), and the survey and interview results from the case study. 
The RMAF's Present Practices in Comparison with Literature, Malaysian public sector, RMN, RMA, DOD USA, $M O D U K$ and $A D F$

The comparison is shown in Table 10.

Table 10. RMAF's present practices in comparison with literature, RMN, RMA, Malaysian public sectors, DoD USA, MoD UK and ADF

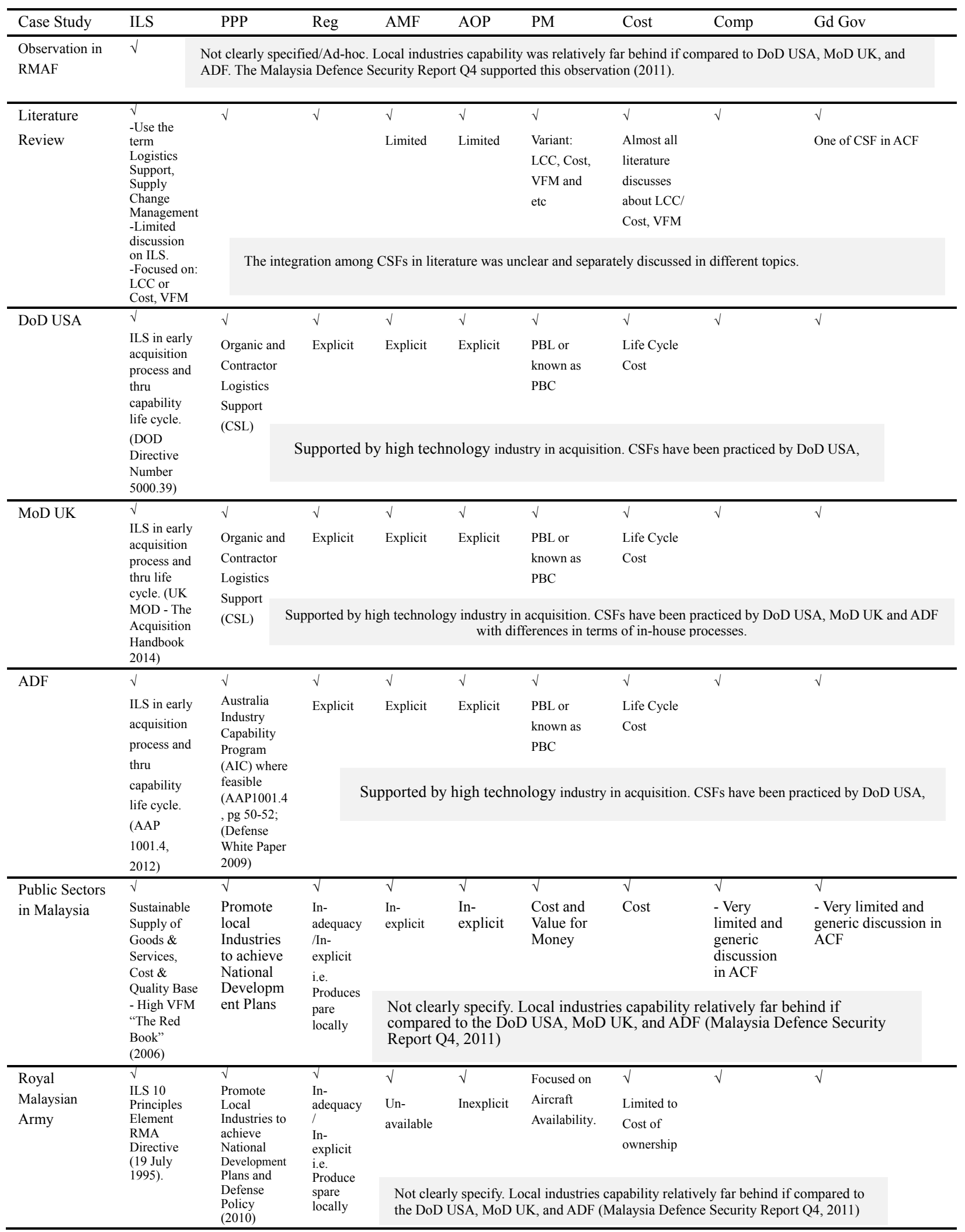




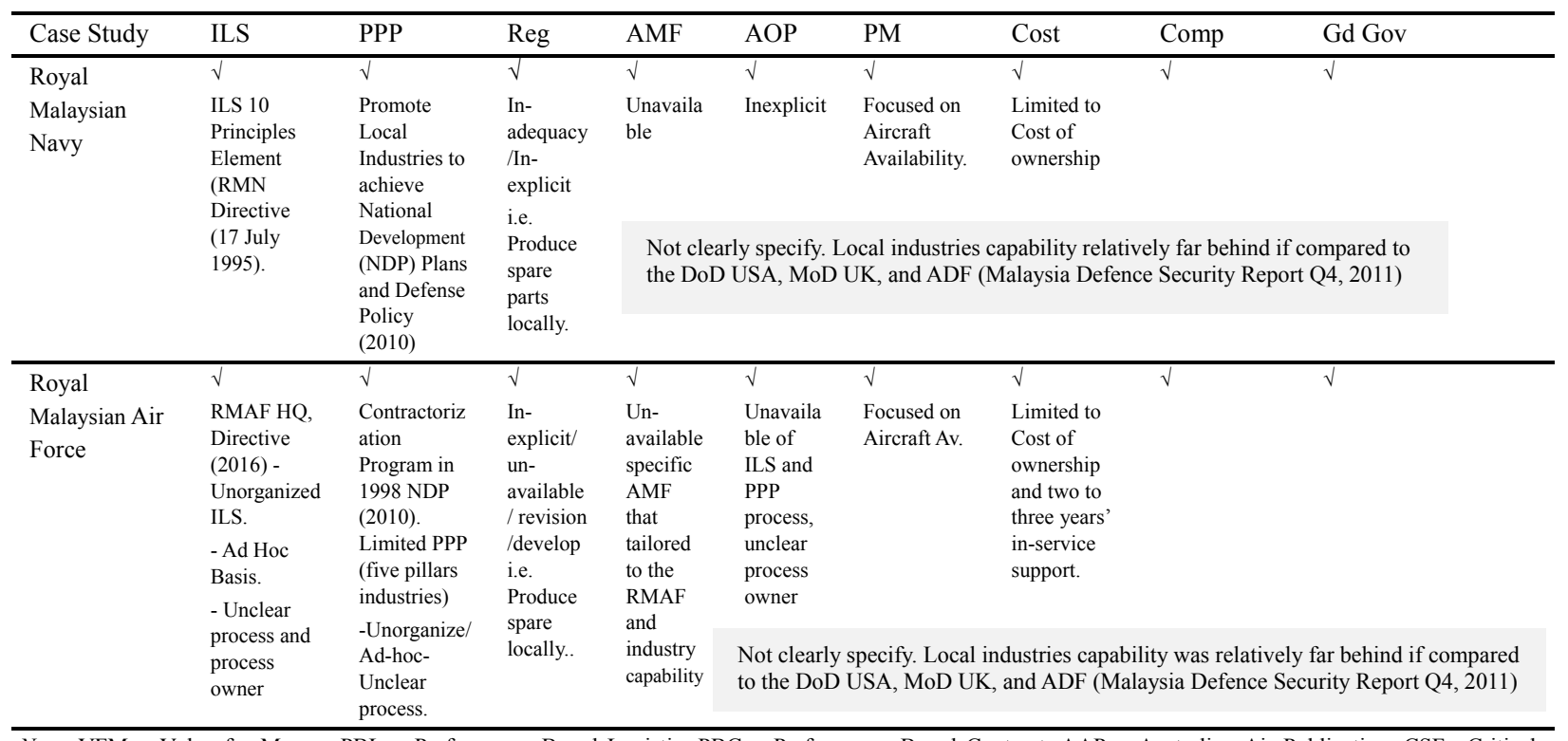

Note. VFM $=$ Value for Money, $\mathrm{PBL}=$ Performance Based Logistic, $\mathrm{PBC}=$ Performance Based Contract, $\mathrm{AAP}=\mathrm{Australian}$ Air Publication, $\mathrm{CSF}=\mathrm{Critical}$ Success Factor, $\mathrm{ACF}=$ Acquisition Conceptual Framework, Comp $=$ Competency of personnel, Gd Gov $=$ Good governance in acquisition, and PM $=$ Performance Measure.

\subsection{Major Findings}

There were three major findings:

Conclusion 1: RMAF has not achieved and sustained at least $70 \%$ aircraft Av as its desired objective due to high aircraft downtime waiting for spares at RMAF facilities (AWP), and waiting for spares at second line or contractor facilities (CONT). The percentage of three aircraft Av from year 2011 to 2015: Type A, Type B and Type $\mathrm{C}$ is approximately $43 \%$ which is far from the targeted $70 \% \mathrm{Av}$. Aircraft downtime is due to AWP (23.5\%) and CONT (25\%) which exceed the target of $10 \%$ or below. Downtime due to in-work by technician (IWRK) is below $10 \%$ and within the target limits. As such, reducing or eliminating the AWP and CONT ensures higher aircraft availability. This answers Research Question One on why RMAF has not achieved and sustained at least $70 \%$ of aircraft availability.

Conclusion 2: Weaknesses in the RMAF's present acquisition conceptual framework (ACF) have caused ineffectiveness and inefficiency of through life cycle support (TLCS) and it has given a significant impact to aircraft Av in terms of higher aircraft downtime due to AWP and CONT. The weaknesses in the RMAF's present practices are related to the critical success factors (CSFs) in ACF. Hence, based on the literature review, observation in the field and case studies results, this research has identified CSFs in ACF. These CSFs are integrated logistics support (ILS), ecosystem for public-private participation (PPP) in aerospace defence industry, support regulations and policy related to aircraft acquisition, acquisition operational process (AOP), life cycle cost (LCC), performance measurement (PM), acquisition management framework (AMF), competency of the RMAF personnel involved in the acquisition process, and good governance. There are 30 elements associated to acquisition. The 19 elements taken from literature are performance based logistics (PBL), safety \& reliability centered maintenance (Safety \& RCM), failure mode, effect and criticality analysis (FMECA), logistics support analysis (LSA), logistics support analysis record (LSAR), computer aided logistics support (CALS), reliability, availability and maintainability (RAM), total life cycle support (TLCS), and level of repair analysis (LORA). In addition, the literature had also highlighted the importance of maintenance planning, technical data, manpower and personal, supply support, support and test equipment, computer resource support, facility, packaging handling storage and transportation (PHS\&T) e.g. NATO standards PHS\&T, design interface, and binding contracts. 6 elements from the case study results consist of: development/revision of regulations and policy in spares parts manufacture, obsolescence management, pre-delivery inspection (PDI), final acceptance test (FAT), mid - life review, smart partnership RMAF and industry, acquisition management framework (AMF), integrated logistics support (ILS), and acquisition operational process (AOP). Furthermore, acquisition requires explicit public-private participation process flow and process owner, to avoid ad-hoc implementation, preparedness: for ILS, transfer of technology (ToT) and innovation through offset program, high competency and advance technology maintenance repair and overhaul (MRO), and supported through explicit acquisition process and process owner. 5 elements from validation results consist of: explicit regulations and policy at national level for spare parts manufacture, obsolescence management, mid - life review, smart partnership and self-reliance 
concept. Furthermore, the industry's early involvement in the acquisition process (concept phase) under the win-win situation concept, a fair chance for the industry to participate and do not focus only on five core companies, industry preparedness e.g. MRO acquire competencies through ToT in offset programs and priority given to local companies to participate rather than to OEM or overseas vendors. By successfully identifying the areas of improvement in the RMAF's present practices, this research finding has answered Research Question Two: How has the RMAF's present practices given a significant impact to aircraft availability. The areas of concern in the present ACF are as follows:

a. The present ILS with ten principle elements and ten supporting elements in the RMAF is not organized and has limited applicability. It was on an ad hoc basis with an unclear process and process owner. $\mathrm{b}$.

Even though the ecosystem for PPP in the aerospace defence industry is available, it is not organized with an unclear process and process owner, and is practiced on an ad hoc basis. There is limited PPP in aircraft maintenance activities with focus on the industry's core companies: Airod Sdn Bhd, Destini Prima Sdn Bhd, Sapura Sdn Bhd, ATSC Sdn Bhd, and Zetro Services Sdn Bhd. Other industry players have limited opportunity to contribute.

c. RMAF does not have a specific AMF tailored to its specific requirements in-line with the local industry's capability. These findings were further supported by interview results with the management group.

d. There are unclear regulations at the national level focusing on spare parts manufacturing by the local industry along with the unavailability or inadequacy of policies to support the aircraft acquisition process.

e. AOP is made available, but there is no process and unclear process owner for the ILS and PPP processes in the AOP. This situation has contributed to areas of concern in ILS and PPP for the aerospace defence industry throughout the acquisition process.

f. Performance measures are focused on aircraft availability during the operational phase rather than performance based logistics or performance based contract throughout the whole aircraft's life cycle.

g. There is limited discussion on LCC calculations. Normally, calculation of cost is limited to the cost of ownership with additional two to three years in-service support contract. Subsequent support is normally based on ad hoc basis.

h. Governance within the RMAF must be well disseminated and understood so that the acquisition process can be carried out efficiently.

Conclusion 3: The acquisition frameworks used by the DoD USA, MoD UK, and ADF are not suitable for the RMAF because they are supported by advanced technology industries compared to Malaysia where the aviation industry is still in the infant stage. The RMAF needs to have its own ACF to suit its unique military requirements (e.g. robust operations, risky flying areas and etc) and to be compatible to the local industry's capability in the present ecosystem. The present ACF in the RMAF is not organized as it is ad hoc with unclear process and process owner. It needs to be reorganized through integration with the identified 9 CSFs and 30 elements associated with acquisition as shown in Figure 5. Improvement in ACF through proper implementation can reduce aircraft downtime due to AWP and CONT. By successfully identifying the CSFs and integrating all of them in ACF III for implementation, this research finding has answered Research Question Three: What is the recommended acquisition conceptual framework that suits the RMAF and helps in ensuring high aircraft availability?

\subsection{Research Contributions}

The project under study is expected to close the gaps, provide a TLCS, deliver the following results and help in achieving and sustaining of at least $70 \%$ aircraft $\mathrm{Av}$ at all times:

a. Successfully identify the cause of why the RMAF has not achieved aircraft availability as its desired objective.

b. Successfully identify the RMAF's present acquisition practices and its significant impact to aircraft availability.

c. Successfully propose an aircraft acquisition conceptual framework that suits the RMAF and helps in ensuring high aircraft availability

\subsection{Recommendation for Future Work}

This study had focused on military aircraft in the RMAF. Therefore, the application of study results on other 
weapon systems, civil aviation aircraft or other sectors might be limited and require further research.

\section{Summary}

The RMAF has had difficulties in achieving and sustaining its aircraft Av as its desired objectives due to high aircraft downtime waiting for spares at the RMAF facilities and waiting for spares at the second line or contractor facilities. Weaknesses in the acquisition conceptual framework have caused ineffectiveness and inefficiency in the aircraft's through life cycle support and has given a significant impact to aircraft availability. An effective and efficient acquisition conceptual framework to suit the RMAF's unique requirements e.g. robust equipment was achieved through the integration of 9 critical success factors and 30 elements associated to acquisition. The 9 CSFs in acquisition consist of integrated logistics support, a healthy ecosystem for public-private participation in aerospace defence industry, a clear acquisition management framework, explicit regulations, policy and procedures (especially on spare manufacturing by local industries), a clear acquisition operational process, performance based logistics contract, and competency of personnel and good governance in acquisition process. Those CSFa ensure the aircraft Through Life Cycle Support, lower percentage of aircraft downtime, high percentage of availability as per the RMAF's desired objective. 30 elements associated to acquisition consist of PBL, RCM, FMECA, LSA, LSAR, CALS, RAM, TLCS, LORA, maintenance planning, technical data, manpower \& personal, supply support, support \& test equipment, computer resource support, facility, PHS\&T, design interface and binding contract. All agreements must be in the form of binding contracts. The findings answered the problem statement of why the aircraft in the RMAF fleet has yet to achieve and sustain at least $70 \%$ of availability from the total aircraft in inventory. An effective acquisition conceptual framework ensures higher aircraft availability and helps in RMAF readiness to support the six basic principles of the Malaysian Defence Policy which are the capability for self-reliance, supporting the United Nations in peacekeeping, commitment to the Five Countries Defence Policy, steps taken on terrorism, defence diplomacy, and total defence in achieving the main objective to protect and defend the interests that are core to the country's sovereignty, territorial integrity and economic prosperity.

\section{Acknowledgments}

I would like to express my deep appreciation to the following people: First, many thanks to Lieutenant Colonel Samsuri bin Abu Bakar, the Head of Structure and Aerodynamics, Central Aerospace Engineering Services Establishment, Royal Malaysian Air Force. I also thank all Technical and Material staff who were involved during the planning stage of this project. My special gratitude goes to Professor Madya Dr. Abdul Rahman bin Abdul Rahim for his invaluable guidance. I appreciate all of their efforts which had motivated me to complete this project.

\section{References}

Ayhan, B., \& Üstüner, Y., (2015). Governance in public procurement: the reform of Turkey's public procurement system. International Review of Administrative Sciences. DOI:10.1177/0020852314548153

Aldebert, B., \& Rouzies, A., (2014). What role for mixed methods in the French management research? International Management, 19(1), 43-60.

Aguado-Romero, J., Manuel, A., Lo'pez-Herna'ndez, \& Vera-Ri'os, S., (2013). Auditing defence procurement contracts in the European context: An inter-country analysis. International Review of Administrative Sciences, 79(4), 659-680. DOI:10.1177/0020852313502155

Alinaitwe, H., and Ayesiga, R. (2013). Success Factors for the Implementation of Public-Private Partnerships in the Construction Industry in Uganda. Journal of Construction in Developing Countries. 18(2), 1-14.

Abd Rahman bin Abdul Rahim, \& Nabi Baskh M. S. (2003). Case Study Method for New Product Development in Engineer-to-order Organizations. Work Study, 52(1), 25-36.

Australian Defence Force Capability Development Handbook (2012). Director Skilling, Knowledge, Improvement and Policy. Capability Development Group, PO Box 7905, Canberra Bc Act 2610. Australia: Australian Defence Force.

Bellais, R. (2014). Public-private partnerships and the transformation of defence investment in the evolving boundaries of defence: An assessment of recent shifts in defence activities. Published online: 08 Oct 2014; $25-49 \mathrm{c} 2.4 .2$

Burgess, K., \& Balakrishnan, K. (2014). Challenges in matching performance metrics to defence acquisition. IJDAM, 6, 66-77.

Bowyer, D., \& Davis, G. (2012). How to acquire aircraft? A grounded theory approach to case study research. Qualitative research in accounting and management, 9(4), 363-397. 
Bhattacherjee, A. (2012). Social science research: principles, methods and practices (2nd ed). PHD, University of South Florida.

Bowen, G. A. (2008). Naturalistic Inquiry and Saturation Concept: A Research Note. 8(1) 137-152. London: Sage Publications.

Beesly, L. R. (1966). Some Aspects of Military Aircraft Procurement. Aircraft Engineering and Aerospace Technology. 38(10), 26-36.

Chad, D., \& Stephen, H. (2015). A conceptual framework for defence acquisition decision makers. Defence acquisition research journal: A publication of the Defense Acquisition University, 21(1), 485-504.

Caldwell, N., \& Howard, M., (2014). Contracting for complex performance in markets of few buyers and sellers: The case of military procurement. International Journal of Operations \& Production Management, 34(2), 270-294.

Cheung, E., Chan, A. P. C., \& Kajewski, S. (2010). Suitability of Procuring Large Public Works by PPP in Hong Kong. Engineering, Construction and Architectural Management. 17(3), 292-308.

Crotts, J. C., Pan, B., \& Raschid, A. E. (2008). Research in brief - A survey method for identifying key drivers of guest delight. International Journal of Contemporary Hospitality Management, 20(4), 462-470. DOI:10.1108/09596110810873552

Durugbo, C., \& Erkoyuncu, J. A. (2016). Mitigating uncertainty for industrial service operations: A multi case study. International Journal of Operations \& Production Management, 36(5), 532-571.

Davids, C., Beeres, R., Paul C., \& Fenema, V. (2013). Operational defense sourcing: Organizing military logistics in Afghanistan. International Journal of Physical Distribution \& Logistics Management, 43(2), 116-133

Delano, K. J. (1999). Critical Success Factors for DoD Program Managers. Thesis. Air Command and Staff College, Air University, Maxwell Air Force Base, Alabama.

Eßig, M., Mohr, D., \& Tandler, S. (2014). An expose - capacity - portfolio for defence supply chains - The case of the military airlifter A400M. http://www.acquisitionjournal.org. International Journal of Defense Acquisition Management (IJDAM), 6(2014), 1-20.

Euske, K. J., Miguel, J. S., \& Wang, C. (2012). How does the cost performance of defense contracts vary among services and contractors? Evidence from Major Defense Acquisition Programs (MDAP). In M. J. Epstein, \& J. Y. Lee (Eds.), Advances in Management Accounting (Vol. 20, pp. 75-100). Emerald Group Publishing Limited. http://dx.doi.org/10.1108/S1474-7871(2012)0000020010.

Ellis, L. (1994). Research Methods in the Social Sciences. USA: Wm. C. Brown Communications, Inc.

Fielding, J. P. (1980). How Do Aircraft Break Down? Some Studies of Reliability Data Feedback. Aircraft Engineering and Aerospace Technology. 52(11), 15-19.

Gaither III, C. C. (2014). Incorporating Market Based Decision Making Processes in Defence Acquisitions. IJDAM. 6(2014), 38-50.

Glas, A., Hofmann, E., \& Eßig, M. (2013). Performance-based logistics: A portfolio for contracting military supply. International Journal of Physical Distribution \& Logistics Management, 43(2), 97-115.

Salehi, K., \& Golafshani, N. (2010). Using Mixed Methods in Research Studies: An Opportunity With the Challenges. International Journal of Multiple Research Approaches, 4(3), 186-191.

Graham, G., \& Hardaker, G. (1998). Defence Sector Procurement and Supply Chain Relationships. Supply Chain Management: An International Journal, 3(3), 142-148.

Gregory, R. N. (1992). The Impact of Life Cycle Cost on Procurement Decisions, SAE Technical Paper. Doi:10.4271/920969.

Hui, W. S., Othman, R., Omar, N. H., Rahman, R. A., \& Haron, N. H. (2011). Procurement issues in Malaysia. International Journal of Public Sector Management, 24(6), 567-593.

Humphries, A., \& Wilding, R. (2004). Sustained Monopolistic Business Relationships. European Journal of Marketing, 38(1/2), 99-120.

Ianakiev, G. (2014). Defence Offsets: Regulation and Impact on the Integration of the European Defence Equipment Market. In The Evolving Boundaries of Defence: An Assessment of Recent Shifts in Defence Activities.

Juanita, M., Rendon Rene, \& Rendon G. (2016). Procurement Fraud in the US Department of Defence. Managerial Auditing Journal, 31(6/7), 748-767.

Jefferies, M., Brewer, G. J., \& Gajendran, T. (2014). Engineering, construction and architectural management, 
21(5), 465-80. Emerald Country of Publication: UK.

Janes, J. (2001). On research - Survey research design. Library High Tech., 19(4), 419-421. MCB University Press.

Kevin M., Robert T., Allen, W., \& Grigg, L. (2014). Performance Metrics Analysis for Aircraft Maintenance Process Control. Journal of Quality in Maintenance Engineering, 20(2), 122-134.

Khotari, C. R. (2005). Research Methodology-Methods and Techniques (2nd revised ed.) New Delhi: New Age International (P) Limited, Publishers.

Lavallee, T. M. (2010). Bulletin of Science. Technology \& Society, 30(3), 185-194.

Likert, R. (1932). A Technique for Measurement of Attitudes. Archives of Psychology, 21(40).

Maxim, P. S. (1999). Quantitative Research Methods in the Social Sciences. New York: Oxford University Press, Inc.

Miller, A., \& Ray, J. L. (2015). Moving from best practices to standard practices in defense acquisition. Defense Acquisition Research Journal: A Publication of the Defense Acquisition University, 22(1), 64-82.

MoD UK JSP 886 (2012). Integrated Logistic Support Policy. Volume 7, Part 1, Version 2.4. United Kingdom: MoD.

MoD UK JSP 886 (2014). Integrated Logistic Support Policy. Chapter 3, Volume 7, Part 1, Version 2.6. United Kingdom: MoD.

Mohammad Reza Mohammadi (2013). Ranking of Critical Success Factors of e-procurement in Iranian Automotive Industry. International Research Journal of Applied and Basic Sciences, 4(12), 3910-3918.

Parida, A., Kumar, U., Galar, D., \& Stenström, C. (2015). Performance Measurement and Management for Maintenance: A Literature Review. Journal of Quality in Maintenance Engineering, 21(1), 2-33.

Perez, M., Urbina, L. S., Damiani J. H. S. (2009). Acquisition and Development Methodology of Aircraft, Systems and Materials of the Brazilian Air Force. Management of Engineering \& Technology (MET), 2009. PICMET 2009 Proceedings, August 2-6, Portland, Oregon USA: PICMET.

PeriyarSelvam, U., Tamilselvan, T., Thilakan, S., and Shanmugaraja, M. (2013). Analysis on Costs for Aircraft Maintenance. Advances in Aerospace Science and Applications (2013), 3(3), 177-182.

Pryor, W. E., \& M. B. E. (1964). Reliability and Performance of Aircraft Transparencies in Military Service. Aircraft Engineering and Aerospace Technology, 36(12), 386-402.

Ribeiro, C. G., \& Furtado A. T. (2014). Science, Technology \& Society, 19(2), 161-197.

Rosen, S., G. (2013). Defense Acquisition Research Journal: A Publication of the Defense Acquisition University, 20(3), 261-282.

Rutner, S. M., Aviles, M., \& Cox, S. (2012). Logistics Evolution: A Comparison of Military and Commercial Logistics Thought. The International Journal of Logistics Management, 23(1), 96-118.

Rong, Z., Yunxiang, C., \& Chungrong, H. (2010). Acquisition Strategy of Complicated Equipment Based on Optimization Theory. ICEEE: E-Product, E-Service and E-Entertainment. 7-9 Nov 2010. Henan, China: 1, 227- 230.

Raymond, J. (2008). Benchmarking in Public Procurement. Benchmarking: An International Journal. 15(6), 782793. http://dx.doi.org/10.1108/14635770810915940

RMAF HQ PU 2102 (2012). RMAF Engineering Organization Quality Manual Clause 5.4.1c. Malaysia: RMAF.

RMAF HQ PU 2302 (2012). Engineering Organization Procedure Manual: The Planning of the Engineering Organization Resources. Malaysia: RMAF.

Star, M. A. (2014). Qualitative and Mixed-Methods Research In Economics: Surprising Growth, Promising Future. Journal of Economic Surveys, 28(2), 238-264.

Sokri, A. (2014). Life Cycle Costing of Military Equipment. Proceedings of the International Conference of Control, Dynamic Systems, and Robotics. 15-16 May 2014. Ottawa, Ontario, Canada, Paper No. 45

Schwartz, M. (2013). Defense Acquisitions: How DOD Acquires Weapon Systems and Recent Efforts to Reform the Process. Congressional Research Service. USA: 1 - 16.

Stewart, J., \& Ablong, T. (2013). When Australian Defence Procurement Goes Wrong: Improving Outcomes in a Troubled Contractual Environment. The Economic and Labour Relations Review. Non - Symposium Article. UK: Sage Publication.

Sekaran, U., \& Bougie, R. (2009). Research Methods for Business, A Skill Building Approach (5th ed.). USA: John Wiley and Sons, Ltd, Publication. 
Samaranayake, P., Lewis G. S., Woxvold E. R. A., \& Toncich, D. (2002). Development of Engineering Structures for Scheduling and Control of Aircraft Maintenance. International Journal of Operations \& Production Management, 22(8), 843-867.

Salant, P., \& Dillman, D. A. (1994). How to Conduct Your Own Survey? USA: John Wiley \& Sons Inc.

Tashakkori, A., \& Teddlie, C. (Eds.) (2010). Sage Handbook of Mixed Methods in Social \& Behavioral Research (2nd ed.) Thousand Oaks, CA: Sage Publications.

Terry, D. Moore Alan, W., Johnson Michael, T., Rehg Michael J., \& Hicks (2007). Quality assurance staffing impacts in military aircraft maintenance units. Journal of Quality in Maintenance Engineering, 13(1), $33-48$.

Umar Al-Turki (2011). A Framework for Strategic Planning in Maintenance. Journal of Quality in Maintenance Engineering, 17(2), 150-162.

DoD USA (2013). Defence Acquisition Guidebook. USA: DoD.

DoD USA Acquisition University (DAU) Press (2016). Defense Acquisition Acronyms and Terms. (16 $6^{\text {th }}$ ed.) Fort Belvoir, Virginia: DoD USA.

DoD USA Federal Acquisition Regulation (FAR) 2.101 (2016). USA: DoD.

DoD USA DODI 5000.02 (2015). Operation of the Defense Acquisition System. Washington DC USA: Government Printing Office.

DoD USA Army Regulation 700-127 (2014). Logistics - Integrated Product Support. Washington, DC: DoD USA Headquarters Department of the Army.

Department of Commerce USA (2012). Offsets in Defense Trade Sixteenth Study: Conducted Pursuant to Section 723 of the Defense Production Act of 1950, as Amended, Bureau of Industry and Security. USA: DoD.DoD USA Defence and Security Report Q4 (2010). Includes 5-Year Forecast to 2014. London UK: Business Monitor International Ltd, pp 8.

Vucetic, S. (2016). Who Framed the F-35? Government-Media Relations in Canadian Defence Procurement. International Journal, 71(2), 231-248.

Venelin, G., (2010). Modeling Defense Acquisition Strategy. Consortium of Defense Academies and Security Studies Institutes Fall 2010. The Quarterly Journal, 9(4), 53-68.

Worger, D., Jalao, E. R., Wirthlin, J. R., Colombi, J., \& Wu, T. (2014). Intervention Strategies for the Department of Defense Acquisition Process. Journal of Defense Modeling and Simulation: Applications, Methodology, Technology, 13(2), 139-151.

Woodford, S., \& Smith, H. (1998). The Minimization of Combat Aircraft Life Cycle Costs through Conceptual Design Optimization. 1998 World Aviation Conference September 28-30. Anaheim, CA.

Yin, R. K. (1994). Case Study Research: Design and Methods (2nd ed.) London: Sage Publications.

\section{Copyrights}

Copyright for this article is retained by the author(s), with first publication rights granted to the journal.

This is an open-access article distributed under the terms and conditions of the Creative Commons Attribution license (http://creativecommons.org/licenses/by/4.0/). 